\title{
Mercury in the Southern Ocean
}

\author{
Daniel Cossa ${ }^{\mathbf{a},{ }^{*},}$, Lars-Eric Heimbürger ${ }^{\mathbf{a}}$, Delphine Lannuzel ${ }^{\mathbf{b}, \mathbf{c}}$, Stephen R. Rintoul ${ }^{\mathbf{b}, \mathbf{d}, \mathbf{e}}$, \\ Edward C.V. Butler ${ }^{\mathbf{b}, \mathbf{d}, \mathbf{e}}$, Andrew R. Bowie ${ }^{\mathbf{b}}$, Bernard Averty ${ }^{\mathbf{f}}$, Roslyn J. Watson ${ }^{\mathbf{d}}$ and Tomas Remenyi ${ }^{\mathbf{b}}$

\footnotetext{
a Ifremer, Centre for the Mediterranean Sea, BP 330, F.83507 La Seyne sur Mer, France

${ }^{b}$ Antarctic Climate and Ecosystems Cooperative Research Centre (ACE CRC), Hobart, Tasmania 7001, Australia

${ }^{\mathrm{c}}$ Institute for Marine and Antarctic Studies, Hobart, Tasmania 7001, Australia

d Centre for Australian Weather and Climate Research (CAWCR), Hobart, Tasmania 7000, Australia

e Wealth from Oceans National Research Flagship, CSIRO Marine and Atmospheric Research, Hobart, Tasmania 7001, Australia

${ }^{\mathrm{f}}$ Ifremer, Nantes Centre, BP 21105, F.44311 Nantes Cedex 03, France
}

*: Corresponding author : Daniel Cossa, email address : $\underline{\text { dcossa@ifremer.fr }}$

\begin{abstract}
:
We present here the first mercury speciation study in the water column of the Southern Ocean, using a high-resolution south-to-north section $\left(27\right.$ stations from $65.50^{\circ} \mathrm{S}$ to $\left.44.00^{\circ} \mathrm{S}\right)$ with up to 15 depths (0$4440 \mathrm{~m}$ ) between Antarctica and Tasmania (Australia) along the $140^{\circ} \mathrm{E}$ meridian. In addition, in order to explore the role of sea ice in $\mathrm{Hg}$ cycling, a study of mercury speciation in the "snow-sea iceseawater" continuum was conducted at a coastal site, near the Australian Casey station $\left(66.40^{\circ} \mathrm{S}\right.$; $\left.101.14^{\circ} \mathrm{E}\right)$. In the open ocean waters, total $\mathrm{Hg}\left(\mathrm{Hg}_{\mathrm{T}}\right)$ concentrations varied from 0.63 to $2.76 \mathrm{pmol} \mathrm{L}^{-1}$ with "transient-type" vertical profiles and a latitudinal distribution suggesting an atmospheric mercury source south of the Southern Polar Front (SPF) and a surface removal north of the Subantartic Front (SAF). Slightly higher mean $\mathrm{Hg}_{\mathrm{T}}$ concentrations $\left(1.35 \pm 0.39 \mathrm{pmol} \mathrm{L}^{-1}\right)$ were measured in Antarctic Bottom Water (AABW) compared to Antarctic Intermediate water (AAIW) $\left(1.15 \pm 0.22 \mathrm{pmol} \mathrm{L}^{-1}\right)$. Labile $\mathrm{Hg}\left(\mathrm{Hg}_{\mathrm{R}}\right)$ concentrations varied from 0.01 to $2.28 \mathrm{pmol} \mathrm{L}^{-1}$, with a distribution showing that the $\mathrm{Hg}_{\mathrm{T}}$ enrichment south of the SPF consisted mainly of $\mathrm{Hg}_{\mathrm{R}}(67 \pm 23 \%)$, whereas, in contrast, the percentage was half that in surface waters north of PFZ $(33 \pm 23 \%)$. Methylated mercury species $\left(\mathrm{MeHg}_{\mathrm{T}}\right)$ concentrations ranged from 0.02 to $0.86 \mathrm{pmol} \mathrm{L}^{-1}$. All vertical $\mathrm{MeHg}_{\mathrm{T}}$ profiles exhibited roughly the same pattern, with low concentrations observed in the surface layer and increasing concentrations with depth up to an intermediate depth maximum. As for $\mathrm{Hg}_{\mathrm{T}}$, low mean $\mathrm{MeHg}_{\mathrm{T}}$ concentrations were associated with AAIW, and higher ones with AABW. The maximum of $\mathrm{MeHg}_{\mathrm{T}}$ concentration at each station was systematically observed within the oxygen minimum zone, with a statistically significant $\mathrm{MeHg}_{\mathrm{T}}$ vs Apparent Oxygen Utilization (AOU) relationship $(p<0.001)$. The proportion of $\mathrm{Hg}_{\mathrm{T}}$ as methylated species was lower than $5 \%$ in the surface waters, around $50 \%$ in deep waters below $1000 \mathrm{~m}$, reaching a maximum of $78 \%$ south of the SPF. At Casey coastal station $\mathrm{Hg}_{\mathrm{T}}$ and $\mathrm{Hg}_{\mathrm{R}}$ concentrations found in the "snow-sea ice-seawater" continuum were one order of magnitude higher than those measured in open ocean waters. The distribution of $\mathrm{Hg}_{\mathrm{T}}$ there suggests an atmospheric $\mathrm{Hg}$ deposition with snow and a fractionation process during sea ice formation, which excludes $\mathrm{Hg}$ from the ice with a parallel $\mathrm{Hg}$ enrichment of brine, probably concurring with the $\mathrm{Hg}$ enrichment of AABW observed in the open ocean waters. Contrastingly, $\mathrm{MeHg}_{\mathrm{T}}$ concentrations in the sea ice environment were in the same range as in the open ocean waters, remaining below $0.45 \mathrm{pmol} \mathrm{L}^{-1}$. The $\mathrm{MeHg}_{\mathrm{T}}$ vertical profile through the continuum suggests different sources, including atmosphere, seawater and methylation in basal ice. Whereas $\mathrm{Hg}_{T}$ concentrations in the water samples
\end{abstract}


collected between the Antarctic continent and Tasmania are comparable to recent measurements made in the other parts of the World Ocean (e.g., Soerensen et al., 2010), the Hg species distribution suggests distinct features in the Southern Ocean $\mathrm{Hg}$ cycle: (i) a net atmospheric $\mathrm{Hg}$ deposition on surface water near the ice edge, (ii) the $\mathrm{Hg}$ enrichment in brine during sea ice formation, and (iii) a net methylation of $\mathrm{Hg}$ south of the SPF.

Keywords : mercury, methyl mercury, water column, sea ice, Southern Ocean, Antarctica

\section{Introduction}

Mercury is widely distributed in the oceans as a result of long-54 range atmospheric transport and deposition by wet and dry processes. The stability of its neutral and volatile species (mainly elemental $(\mathrm{HgO})$ and dimethylmercury $(\mathrm{DMHg})$ ) and the reactivity of its charged species (mainly chlorocomplexes) causes it to be intensively recycled between the lower troposphere and the ocean surface, and actively scavenged by particula matter (e.g., Mason and Gill, 2005). All chemical forms are intricately linked together through the divalent pool (Hgll), by various chemical reactions and microbiological transformations, such as methylation/demethylation and oxidation/reduction reactions (see reviews by Mason and Gill, 2005 and Fitzgerald et al., 2007). Methylation/demethylation reactions control the abundance of monomethylmercury $(\mathrm{MMHg})$ in seawater, a neuro-toxic species that is biomagnified in the food web, posing health $s$ for consumers of marine seafood. Oxidation/reduction reactions influence the transfer of mercury between surface water and the troposphere. Many of these reactions involve phase changes, which, combined with spatial variations in ocean circulation, $\mathrm{t}$ intensity of the biological pump and the deposition of $\mathrm{Hg}$, can generate large spatial heterogeneity in the distribution of the various $\mathrm{Hg}$ species.

Because of the analytical challenges of measuring $\mathrm{Hg}$ species concentrations in oceanic waters, the distribution of $\mathrm{Hg}$ species in the main oceanic water masses is still poorly documented (see reviews by Fitzgerald and Lamborg, 2003; Mason and Gill, 2005; Fitzgerald et al., 2007; Sunderland and Mason, 2007). The Atlantic and North Pacific oceans, and the Mediterranean Sea are the most investigated regions (Mason and Fitzgerald, 1990, 1992 and 1993; Cossa et al., 1997, 2009; Mason and et al., 1998, and 2001; Mason and Sullivan 1999; Horvat el al., 2003, Kotnick et al., 2007; Laurier et al., 2004; Cossa and Coquery, 2005; Heimbürger et al., 2010), but few measurements have been made in other major open ocean regions, such as the Indian, the South Pacific, the Central Arctic, and the Southern Oceans. One exception is a study by Pongratz and Heumann (1998) who reported $\mathrm{MMHg}$ and $\mathrm{DMHg}$ concentrations in surface and subsurface sea-water samples from the English Channel in the North At ic $\left(51^{\circ} \mathrm{N}\right)$ to pack-ice border of Antarctica $\left(58^{\circ} \mathrm{S}\right)$. Furthermore, due to the lack of precision of measurements at the subpicomolar level, the observed distributions have failed, until $\mathrm{n}$ to reveal systematic horizontal geographical trends consistent with the oceanic circulation and biological characteristics, with the 
sole exception being the observation of higher $\mathrm{Hg}$ concentrations in Atlantic surface waters compared to those found in the Pacific (Mason and Gill, 2005). Conversely, systematic vertical trends have been shown, with $\mathrm{Hg}_{\mathrm{T}}$ profiles typical of "particle reactive" or "transient" trace elements, such as $\mathrm{Pb}$, implying a short residence time the ocean (Bruland and Lohan, 2003; Fitzgerald et al., 2007). This is the case for Pacific Ocean and Mediterranean Sea $\mathrm{Hg}_{\mathrm{T}}$ distributions in the water column, with elevated concentrations in surface water consistent with an atmospheric $\mathrm{Hg}$ source (Laurier et al., 2004; Cossa Coquery, 2005). While the $\mathrm{Hg}_{\mathrm{T}}$ pattern describes the overall behavior of $\mathrm{Hg}$, the vertical distributions of particular chemical species reveal contrasting behaviors. Both $\mathrm{MMHg}$ and $\mathrm{DMHg}$ are present in very low concentrations in surface water, due to the instability of these molecules in light (Bergquist and Blum, 2007), and increase with depth, peaking in the low oxygen region, where net $\mathrm{Hg}$ methylation by microbial activity, driven by the decomposition of the sinking $\mathrm{P}$, is assumed to take place (Mason and Fitzgerald, 1990; Cossa et al., 2009; Sunderland et al., 2009; Heimbürger et al., 2010). $\mathrm{Hg}^{0}$ is found both at the surface, as the result of photochemically and biologically mediated reduction of $\mathrm{Hg}^{\mathrm{II}}$, and at depth as the end product of the decomposition of methylated species (Mason and Fitzgerald, 1993; Mason and Gill, 2005).

Polar zones exhibit unique characteristics, chiefly in temperature and light, which make its $\mathrm{Hg}$ cycle unique. The main particularity consists of the rapid oxidation of atmospheric $\mathrm{Hg}^{0}$ as hygroscopic $\mathrm{Hg}^{\mathrm{II}}$ (RGHg for reactive gaseous mercury) in the polar spri e, by sea-saltderived bromine released into the atmosphere during sea ice formation (Schroeder et al., 1998; Lindberg et al., 2001; Ariya et al., 2002). RGHg is deposited onto snow surfaces with a potential transfer to the ocean upon thawing (Lindberg et al., 2 ; Brooks et al., 2008). This phenomenon, called an $\mathrm{Hg}$ depletion event (MDE), was first discovered in the Arctic (Schroeder et al., 1998), then observed in coastal Antarctica (Ebinghaus et al., 2002; Sproveri et al., 2002; Bargalgi et al., 2005). However, while the $\mathrm{Hg}$ cycle in the Arctic has been extensively documented, only a few attempts have been made to study the $\mathrm{Hg}$ cycle in the Southern Polar region. Gaseous elemental mercury $\left(\mathrm{Hg}^{0}\right)$, which is transported on a hemispheric scale (Slerm et al., 1995), is present in slightly higher concentrations $\left(7.7 \pm 1.9 \mathrm{pmol} \mathrm{m}^{-3}\right)$ in the coastal Antarctic marine boundary layer (MBL) compared to more northern sts (e.g., the mean for New Zealand is $5.9 \pm 0.8 \mathrm{pmol} \mathrm{m}^{-3}$ ) (Soerensen et al., 2010). Furthermore, the same authors state that the Antarctic environment exhibits elevated RGHg concentrations $\left(0.21 \pm 0.19 \mathrm{pmol} \mathrm{m}^{-3}\right)$ which are 
114 more than 10-fold the concentrations detected further north. According to a recent review by 115 Dommergue et al. (2010), atmospheric $\mathrm{Hg}$ and ozone depletion events are detectable along the 116 Antarctic sea ice edge, in polynyas, and between pack ice and fast ice, with oxidatio of $\mathrm{Hg}^{0}$ 117 probably more intense than in the Arctic, perhaps due the nearly constant oxidized $\mathrm{Hg}$ 118 enhancement over the sunlit period on the Antarctic co ent. While reductive re-emission of $\mathrm{Hg}$ 119 to the trophosphere remains to be assessed, Dommergue et al. 10) concluded that the fast 120 reactivity of $\mathrm{Hg}^{0}$ and the presence of $\mathrm{Hg}^{\mathrm{II}}$ from late winter to summer may result in an important 121 net input of atmospheric $\mathrm{Hg}$ onto Antarctic surfaces. T very high RGHg concentrations (0.2 $1225.0 \mathrm{pmol} \mathrm{m}^{-3}$ ) (Sproveri et al., 2002; Temme et al., 2003; Soerense et al., 2010) are likely to 123 result in $\mathrm{Hg}$ deposition onto coastal snow packs leading to elevated $\mathrm{Hg}_{\mathrm{T}}$ concentrations (up to $1242140 \mathrm{pmol} \mathrm{L}^{-1}$ ) in the surface snow at the fast-ice edge adjacent to the freezing ocean (Brooks et 125 al., 2008). The same authors suggest $\mathrm{Hg}$ is transferred to the surface seawater in summer during 126 thawing. In addition, high $\mathrm{Hg}$ concentrations (mainly as methylmercury) have been observed in 127 Antarctica biota, despite the long distance from anthropogenic sources (Bargagli, 2008; Bargalgi 128 et al., 2005). Albatross and petrels in the Southern O $\quad$ (SO) have the largest total and methylmercury concentrations yet recorded in seabirds to $680 \mu \mathrm{g} \mathrm{g}^{-1}$, wet weight according to 130 Hindell et al., 1999). This huge bioaccumulation is rather surprising for a supposedly pristine 131 environment, and the origin of methylmercury, the biomagnified $\mathrm{Hg}$ species in marine organisms, 132 in the SO remains unknown.

133 The lack of $\mathrm{Hg}$ observations in the Antarctic environment has prevented identification of the 134 factors controlling the distribution and speciation of mercury in the SO, including the high $\mathrm{Hg}$ 135 bioaccumulation in open-ocean and coastal ecosystems. Here, we present the first $\mathrm{Hg}$ 136 measurements (including total mercury and labile, dissolved gaseous and methylated species) in 137 the water column of the SO, using a high-resolution south-to-north section (27 stations from $13865.5^{\circ} \mathrm{S}$ to $\left.44^{\circ} \mathrm{S}\right)$ with up to 15 depths $(0-4440 \mathrm{~m})$ between Antarctica and Tasmania (Australia) 139 along the $140^{\circ} \mathrm{E}$ meridian (Fig. 1).

140 In addition, in order to explore the role of the sea $\mathrm{i}$ in the $\mathrm{Hg}$ cycling, a special study was 141 devoted to $\mathrm{Hg}$ speciation in the "snow-ice-brine-seawater" continuum at a coastal site, near the 142 Australian Casey station. More specifically, we wanted to address the following questions: (i) 143 what are the level and general distribution of $\mathrm{Hg}_{\mathrm{T}}$ concentrations in the waters of the $\mathrm{SO}$, and is 144 there any indication for sources and sinks? (ii) What re the characteristics of the $\mathrm{Hg}$ speciation 
145 in the waters, which may shed light on $\mathrm{Hg}$ cycling specificity of the SO? (iii) What is the role of 146 the sea ice (formation and melting) in the $\mathrm{Hg}_{\mathrm{T}}$ distribution, speciation and cycling in the SO? And 147 finally (iv) how do our findings contribute to explaining the $\mathrm{Hg}$ hyperbioaccumulation in 148 Antarctic food webs?

\section{SITE}

\subsection{The Southern ocean SR3 CASO-GEOTRACES transect}

The SR3 CASO-Geotraces transect took place between 22 March and 17 April 2008.

153 From south to north, the SR3 section crosses the Southern Antarctic Circumpolar Current Front

154 (SACCF), the Polar Front (SPF), the Subantarctic Front (SAF) and the Subtropical Front (STF)

155 (Orsi et al., 1995; Sokolov and Rintoul, 2002, 2007). ese fronts mark sharp horizontal

156 gradients in water mass properties. Between the fronts lie zones with sim water mass

157 characteristics: the Subtropical Zone (STZ), the Subantarctic Zone (SAZ), the Polar Frontal Zone

158 (PFZ), the Antarctic Zone (AZ), and the Southern Zone Z), between the SACCF and the

159 Antarctic continent.

160 The relatively saline Circumpolar Deep Water (CDW) occupies the largest volume of the

161 Southern Ocean (SO) and lies between the fresher Antarctic Intermediate Water (AAIW) above 162 and fresher Antarctic Bottom Water (AABW) below (Rintoul and Bullister, 1999). The source of

163 CDW is the North Atlantic Deep Water (NADW) exported from the Atlantic Ocean. The CDW is 164 often divided into the Lower CDW (LCDW), corresponding to a deep salinity maximum layer, 165 and the slightly less dense Upper CDW (UCDW), which is defined by an oxygen minimum layer 166 (Rintoul, 2006). The low oxygen of the UCDW is the result of bacterial decomposition of organic 167 matter occurring during the transit of the CDW through the deep layers of the Indian and Pacific 168 basins. The oxygen-poor and nutrient-rich UCDW shoals from north to south across the SO and 169 approaches the surface near the SACCF where it supports high primary production in the AZ and 170 the SZ. Primary productivity in this region is further enhanced by melting sea ice in spring and 171 summer, which both enhances light levels by stabilizing the water column and supplies micro172 nutrients, such as iron (Sullivan et al., 1993; Sedwick and Di Tullio, 1997; Lannuzel et al., 2008). 173 Nutrient concentrations and primary production are generally lower in the SAZ and PFZ. The 
174 poleward flow and upwelling of the UCDW is balanced by sinking and the equatorward flow of

175 Antarctic Intermediate Water (AAIW) and Antarctic Bottom Water (AABW).

176

177

178

179

180

181

182

183

\subsection{The Casey coastal station}

The fast ice study took place in November 2009 in first year sea ice adjacent t "Jack's Donga" hut approximately $12 \mathrm{~km}$ northeast of the Casey Station (Australian East Antarctic sector) $\left(66^{\circ} 13.11^{\prime} \mathrm{S} ; 110^{\circ} 39.03^{\prime} \mathrm{E}\right)$. Our sampling site was located $500 \mathrm{~m}$ off the coast and encircled by islands from the Swain group. Adelie penguin colonies, icebergs, exposed rock moraine and glacial ice surrounded our sampling area. The fast ice was $120 \mathrm{~cm}$ thick, undeformed (i.e., sea ice grew under thermodynamic processes - no rafting involved), level and sitting only 15 to $17 \mathrm{~m}$ above the seafloor.

\section{MATERIAL AND METHODS}

184

\subsection{Southern ocean sampling}

Sampling stations are given in figure 1 , and the coordinates, dates of sampling and ottom depths are given in a supplementary table (Web appendix 1). All sampling methods followed recommended GEOTRACES (www.geotraces.org) protocols as closely as possible. The water column was sampled on the IPY-GEOTRACES section (from Antarctica to Tasmania, Fig. 1) along the $\mathrm{CASO} 140^{\circ} \mathrm{E}$ SR3 meridian during voyage V6 of R/V Aurora Australis. Watercolumn-profile samples were collected using externally closing, Teflon-lined Niskin-1010X® samplers, upon which all remaining metal parts have been replaced by e-metal-clean equivalents, deployed on an autonomous 1018 intelligent rosette system specially developed for trace metal work (General Oceanics Inc., USA) (Bowie et al., 2009). Twenty-seven (27) stations were occupied from $66^{\circ} \mathrm{S}$ to $44^{\circ} \mathrm{S}$, with between 7 and 15 samples collected from the surface down to $4440 \mathrm{~m}$ depth, yielding a total of 241 water sa les. Reactive mercury $\left(\mathrm{Hg}_{\mathrm{R}}\right.$, see section 3.3. below for definition) and dissolved gaseous mercu (DGHg) sub-samples (201 and 59 respectively) were analyzed on board. Sub-samples for total $\left(\mathrm{Hg}_{\mathrm{T}}\right)$ and total methylated mercury species $\left(\mathrm{MeHg}_{\mathrm{T}}\right.$, see section 3.3. below for definition) measurements (71 and 241 respectively) were immediately withdrawn into acid-cleaned Teflon ${ }^{\circledR}$ (FEP) bottles, following ultraclean sample handling protocols within an ISO class-5 clean air laboratory container. Samples were 
201 acidified with $\mathrm{HCl}(0.4 \%$, v/v, Suprapur®, Merck), hermetically sealed, double-wrapped in 202 polyethylene bags, and kept in the dark at $+4^{\circ} \mathrm{C}$ until analysis in the home laboratory.

\section{3.2. Casey station sampling}

All sample preparation and collection techniques were nducted according to Lannuzel et al. (2006). Snow was first collected upwind using acid-cleaned plastic shovels and transferred into polyethylene (PE) containers. Ice cores were then collected using a custom-made corer (Lichtert Industrie, Belgium) designed and tested for ace metal sampling. One top $(0-6 \mathrm{~cm})$, two intermediate $(30-36 \mathrm{~cm}$ and $70-76 \mathrm{~cm})$ and two bottom (lowermost $12 \mathrm{~cm}$ ) ice sections were collected from the same site every 3 days from the $11^{\text {th }}$ until the $20^{\text {th }}$ of November. Ice sections were then placed into individual acid-cleaned PE containers and transported to the station laboratory, where they were melted in the dark at ambient temperature before being processed. Brines were drained from "sack holes" drilled at $50 \mathrm{~cm}$ and $100 \mathrm{~cm}$ deep in the ice cover. The liquid brine was collected using a peristaltic pump ( $\mathrm{M}$ sterflex®, Cole Parmer) coupled with acid cleaned C-Flex tubing. Seawater was collected using a $7 \mathrm{~L}$ polycarbonate (PC) Helmond-Byrne (H-B) sampler attached to a Kevlar® line (Sedwick et al., 1997). The H-B sampler was lowered through the ice cover and triggered at 0,5 and $10 \mathrm{~m}$ depths using an all-Teflon messenger. The collected seawater was decanted into $1 \mathrm{~L}$ acid-washed Low Density Polyethylene (LDPE) Nalgene ${ }^{\circledR}$ bottles, double-bagged and taken back to the Casey station laboratory. Standard trace metal techniques were followed with all laboratory-based processing taking place under a class100 laminar flow hood. Melted sea ice, snow, sack-hole brine and seawater samples were filtered through acid washed $0.2 \mu \mathrm{m}$ PC membrane filters (47-mm diameter, Sterlitech®) and using Sartorius ${ }^{\circledR}$ filtration devices coupled with a vacuum pump (Nalgene $\left.{ }^{\circledR}\right)$. Filtered volumes ranged between 100 and $1000 \mathrm{~mL}$ depending on the type of sample. A $125-\mathrm{mL}$ aliquot from the $<0.2-\mu \mathrm{m}$ fraction was collected in acid-cleaned Teflon® (FEP) bottles, acidified with $50 \mu \mathrm{L} \mathrm{HCl}(0.4 \% \mathrm{v} / \mathrm{v}$ Seastar Baseline ${ }^{\circledR}$, Choice Analytical) sealed, double-bagged, and stored in the dark at $4^{\circ} \mathrm{C}$ until analysis in the home laboratory.

\subsection{Analyses}

All $\mathrm{Hg}$ determinations were made using atomic fluorescence spectroscopy (AFS, Tekran, model $2500 \circledR)$. 
230 Easily reducible mercury (labile), so-called "reactive" mercury $\left(\mathrm{Hg}_{\mathrm{R}}\right)$, was determined on board 231 immediately after sampling in unamended seawater $(50-100 \mathrm{~mL})$. The method consisted of a 232 direct reduction of $\mathrm{Hg}_{\mathrm{R}}$ by an acidic stannous chloride solution $\left(0.002 \mathrm{~mol} \mathrm{~L}^{-1}\right)$, the amalgamation 233 of elemental $\mathrm{Hg}$ on a gold trap, and its subsequent qua cation by AFS. Since the samples were 234 not bubbled before analysis, this $\mathrm{Hg}$ fraction is assumed to represent $\mathrm{Hg}^{0}$ and $\mathrm{Hg}$ ions associated 235 with inorganic or very weak organic complexing agents (Lamborg et al., 2003).

236 Total mercury $\left(\mathrm{Hg}_{\mathrm{T}}\right)$ was determined, within 3 months after sampling, on a ified $(\mathrm{HCl}, 0.4 \% \mathrm{v} / \mathrm{v}$ 237 Suprapur®, Merck) samples, stored in FEP Teflon bottles. The method con $\mathrm{d}$ of an oxidation of 238 the sample with an acidic $\mathrm{BrCl}$ solution $\left(20 \mu \mathrm{mol} \cdot \mathrm{L}^{-1}\right)$, followed by a reduction of the oxidized $\mathrm{Hg}$ 239 by an acidic stannous chloride solution $\left(0.002 \mathrm{~mol} . \mathrm{L}^{-1}\right)$, the amalgamation of the reduced $\mathrm{Hg}$ on a 240 gold trap and its subsequent quantification by AFS. This method is known as the US-EPA method $241 \quad \mathrm{~N}^{\circ} 1631$.

242 Accuracy for $\mathrm{Hg}_{\mathrm{R}}$ and $\mathrm{Hg}_{\mathrm{T}}$ was checked using the CRM ORMS-3 of the National Research 243 Council of Canada and BCR-579 of the Institute for Reference Materials and Measurements for 244 Europe. For means ( $\pm 95 \%$ confidence limits), we found $3.9 \pm 4.5$ pmol.L $\mathrm{L}^{-1}$ (certified value: 62.8 $245 \pm 5.5$ pmol. $\mathrm{L}^{-1}$ ) for ORMS-3 and $1.9 \pm 0.2$ pmol. $\mathrm{L}^{-1}$ for BCR-579 (certified value: $1.9 \pm 0.5 \mathrm{pmol}$ $246 \mathrm{~L}^{-1}$ ). The detection limit, 3 times the standard deviation of 5 blank replicates, was 0.15 pmol. $\mathrm{L}^{-1}$. 247 The analytical reproducibility (5 replicate analyses of the BCR-579) was better than $10 \%$. The 248 reproducibility estimated on a CRM is assumed to be va for the analyzed seawater samples. 249 The possible drift in accuracy during analyses was checked by inserting a CRM every tenth 250 measurement.

251 Dissolved gaseous mercury (DGHg) was also determined on board. The method consisted of a direct 252 bubbling of a $1 \mathrm{~L}$ unamended sample, the amalgamation of elemental $\mathrm{Hg}$ on a gold trap and its 253 subsequent quantification by AFS. This $\mathrm{Hg}$ fraction is umed to represent both dissolved 254 elemental $\mathrm{Hg}$ and the volatile dimethylmercury ( $\mathrm{DGHg}=\mathrm{Hg}^{0}+\mathrm{DMHg}$ ). The AFS calibration for 255 DGHg measurements consisted of injections, every tenth sample, of saturated $\mathrm{Hg}$ vapor at known 256 temperatures through a septum located before the amalgamation trap. The detection limit (3 times 257 the standard deviation of 5 blank replicates) was 0.05 pmol. $\mathrm{L}^{-1}$. Within the range of concentrations 258 measured, the analytical reproducibility was approximately $12 \%$. 
259 We measured monomethylmercury (MMHg) using hydride generation, purge and cryo-trapping 260 gas chromatography, and the detection as elemental $\mathrm{Hg} \quad \mathrm{r}$ by AFS. However, under acidic 261 sample storage conditions $(0.4 \% \mathrm{HCl}, \mathrm{v} / \mathrm{v})$, the measured $\mathrm{MMHg}$ accounts for both methylated 262 species $\left(\mathrm{MeHg}_{\mathrm{T}}=\mathrm{MMHg}+\mathrm{DMHg}\right)$. Indeed, $\mathrm{MMHg}$ is stable in acidified seawater for at least 250 263 days, whereas DMHg rapidly decomposes under similar conditions (Parker and Bloom, 2005). 264 The quantitative conversion of $\mathrm{DMHg}$ into $\mathrm{MMHg}$ in acidified seawater has recently been 265 confirmed (Black et al., 2009). The analytical protocol was designed by Stoichev et al. (2004) 266 and detailed by Cossa et al. (2009). The hydrides are ormed within a glass reactor, and the 267 column used is a glass tube filled with Chromosorb W/AW-DMCS® impregnated with $15 \%$ OV$2683 \circledR$. Within the range of concentrations measured, the analytical reproducibility was approximately $26915 \%$. The detection limit, 3 times the standard deviation of 5 blank replicates, was 0.015 pmol. $\mathrm{L}^{-1}$. 270 Accuracy was checked using the certified reference material (CRM) ERM-AE670 $\left(\mathrm{CH}_{3}{ }^{202} \mathrm{HgCl}\right.$ 271 in $2 \% \mathrm{v} / \mathrm{v}$ ethanol/water, IRMM, European Commission). The $\mathrm{MeHg}_{\mathrm{T}}$ measurements were 272 performed within 2 months after sampling.

273 Dissolved oxygen was measured by Sea-Bird SBE 43® polarographic-type sensor mounted on a 274 CTD rosette incorporating Sea-Bird 9plus ${ }^{\circledR}$ underwater unit. Each profile was recalibrated with 275 data obtained from discrete seawater samples, titrated using a variation of the standard Winkler 276 method with an automatic titration system (Cowley, 1999), based on the method of Knapp et al. 277 (1990). Soluble reactive phosphorus (SRP) concentrations ere determined (along with nitrate278 plus-nitrite and reactive silicon) using an automated colorimetric analyser (Lachat QuikChem 279 8000). For SRP, it is a modification of the standard $\mathrm{m}$ bdenum-blue method (Grasshoff, 1976; 280 Cowley 1999).

\section{RESULTS}

\subsection{Hydrology, oxygen and nutrients}

The salinity, temperature, dissolved oxygen and nutrie distributions (Fig. 2) follow the typical patterns found along the SR3 transect (Rintoul and Bullister, 1999). The SAF was located between $51.0^{\circ} \mathrm{S}$ to $52.7^{\circ} \mathrm{S}$, and SACCF, associated with the upwelling of the Antarctica divergence, at $63.4^{\circ} \mathrm{S}$, and the northern ice pack limit was found in the SZ at $64^{\circ} 4^{\prime} \mathrm{S}$ (Fig. 2). Chlorophyll $a$ distributions in the upper $200 \mathrm{~m}$ along the SR3 transect increased from south to 
north, with very little biomass noted south of $\sim 57^{\circ} \mathrm{S}\left(\mathrm{Chl} a<\sim 0.2 \mu \mathrm{g} . \mathrm{L}^{-1}\right)$. A deep Chla maximum was noted around $110 \mathrm{~m}$ in polar waters at $56^{\circ} \mathrm{S}$, with higher plant biomass in the $\mathrm{SAZ}$, and significantly larger Chla concentrations (> $0.7 \mu \mathrm{g} . \mathrm{L}^{-1}$ ) were observed in subtropical waters north of $46^{\circ} \mathrm{S}$ close to Tasmania. It was likely that biologic uptake along the SR3 transect earlier in the season (spring-summer) resulted in widespread iron limitation during $r$ period of sampling 293 (fall)

\section{2. $\mathrm{Hg}_{\mathrm{T}}$ distribution in the $\mathrm{SO}$}

295

Measured $\mathrm{Hg}_{\mathrm{T}}$ concentrations varied from 0.63 to 2.76 pmol. $\mathrm{L}^{-1}$, with an arithmetical mean of 1.33 pmol.L $\mathrm{L}^{-1}$, a standard deviation of 0.45 pmol.L 1 and a median of 1.20 pmol.L $\mathrm{L}^{-1}$ for the 71 samples analyzed. Seventy-five percent of the values were found between 0.86 and $1.44 \mathrm{pmol} \mathrm{L}^{-}$ ${ }^{1}$. According to our speciation measurements, in deep waters (>200 m) $79 \pm 20 \%$ of $\mathrm{Hg}_{\mathrm{T}}$ consisted of easily reducible mercury and methylated species, whereas the same species accounted for only 37 $\pm 30 \%$ in the upper layer $(<200 \mathrm{~m})$. According to the known $\mathrm{Hg}$ species present in seawater (Mason and Gill, 2005), the unaccounted for $\mathrm{Hg}$ likely consisted of unmethylated organic and "unreactive" inorganic $\mathrm{Hg}^{\mathrm{II}}$ compounds. The former are expected to occur in the biologically productive zone $(<200 \mathrm{~m})$, where organic matter is relatively abundant, the latter deeper in the water column.

The main variations occurred within the upper $200 \mathrm{~m}$ and near the bottom (Fig. 3). This type of vertical distribution is similar to observations in other oceanic regions (Mason and Sullivan, 1999; Laurier et al., 2004; Cossa and Coquery, 2005) and is consistent with the idea that $\mathrm{Hg}_{\mathrm{T}}$ distribution is governed by (i) active air-sea exchange which affects $\mathrm{Hg}^{0}$ concentrations in the mixed layer, and (ii) the affinity of various species of $\mathrm{Hg}^{\mathrm{II}}$ for both planktonic and inorganic particulate matter $\left(\log K_{\mathrm{D}} \sim 5\right)$. Generally, these $\mathrm{Hg}_{\mathrm{T}}$ profiles illustrate a "transient-type" distribution (Fitzgerald et al., 2007), with atmospherically enhanced Hg levels at the surface and scavenging in the upper ocean. Surface $\mathrm{Hg}$ concentrations are comparable with those from the South Atlantic (Mason and Sullivan, 1999), and from the Pacific Ocean (Mason and Fitzgerald, 1993; Laurier et al., 1993), which are $=2$ pmol. $\mathrm{L}^{-1}$. Highest surface $\mathrm{Hg}_{\mathrm{T}}$ concentrations were found at stations $\mathrm{N}-02, \mathrm{~N}-03$, and $\mathrm{N}-08$ south of the SPF and the lowest north of the PFZ (F 3). This distribution suggests an Hg net deposition south $\mathrm{f}$ the SPF and a net surface removal north of the SAF. In deeper layers, $\mathrm{Hg}$ concentrations are relatively constant and consistent with observations in the Pacific Ocean and the Mediterranean Sea (Laurier et al., 2004; Cossa and 
318 Coquery, 2005). In order to examine possible $\mathrm{Hg}_{\mathrm{T}}$ differences linked to a water mass source, we 319 characterized the different water masses found along the transect, based on depth, salinity and temperature (Table 1). We observed slightly different an $\mathrm{Hg}_{\mathrm{T}}$ concentrations: $1.35,1.19$ and 1.15 pmol. $\mathrm{L}^{-1}$, for AABW, CDW, and AAIW, respectively (Table 1). Noteworthy is the facr that the highest mean concentration was found in $\mathrm{AABW}$, with a small difference between AABW and AAIW ( $<<0.15$ for $t$-tests, Table 2). The AAIW mean concentration calculated here is consistent with a measurement made by Mason and Sullivan (1999) in AAIW samples identified much farther north $\left(17^{\circ} \mathrm{S} ; 25^{\circ} \mathrm{W}\right)$ based on values plotte as $0.9 \pm 0.1 \mathrm{pmol} . \mathrm{L}^{-1}$ in the salinity minimum (Figure 8 of their paper).

\section{3. $\mathrm{Hg}_{\mathrm{R}}$ distribution in the $\mathrm{SO}$}

$\mathrm{Hg}_{\mathrm{R}}$ concentrations varied from 0.01 to 2.28 pmol.L $\mathrm{L}^{-1}$, with an arithmetic mean of 0.34 pmol. $\mathrm{L}^{-1}$, a standard deviation of 0.35 pmol. $\mathrm{L}^{-1}$ and a median of 0.33 pmol. $\mathrm{L}^{-1}$ for the 201 samples analyzed. As for $\mathrm{Hg}_{\mathrm{T}}$, the main variations of $\mathrm{Hg}_{\mathrm{R}}$ concentrations occurred within the upper $200 \mathrm{~m}$

331 (Fig. 4) with low concentrations $\left(<0.2\right.$ pmol. $\left.\mathrm{L}^{-1}\right)$ north of the SAF (Stns. N-13 to N-27) and the 332 highest values (> 0.5 pmol. $\mathrm{L}^{-1}$ ) south of the SPF (Stns. N-01 to N-08), notably in the SZ (Fig. 4).

333 This distribution shows that the southerly $\mathrm{Hg}_{\mathrm{T}}$ enrichment (Fig. 3) was mainly present as $\operatorname{Hg}_{\mathrm{R}}(67$ $334 \pm 23 \%)$, whereas, $\mathrm{Hg}_{\mathrm{R}}$ accounted for only half as much $(33 \pm 23 \%)$ in surface waters north of 335 SAF (Stns. N-17 to $\mathrm{N}-27$ ). Intermediate and deep $\mathrm{Hg}_{\mathrm{R}}$ concentrations converged to values around $3360.45 \pm 0.10$ pmol. $\mathrm{L}^{-1}$ without any notable spatial trends. Mean $\mathrm{Hg}_{\mathrm{R}}$ concentrations calculated for the main water masses showed small differences between BW, AAIW and CDW (Table 2).

\section{4.4. $\mathrm{MeHg}_{\mathrm{T}}$ distribution in the SO}

$\mathrm{MeHg}_{\mathrm{T}}$ concentrations ranged between 0.02 to 0.86 pmol. $\mathrm{L}^{-1}$ with an arithmetic mean of 0.29 pmol. $\mathrm{L}^{-1}$, a standard deviation of $0.21 \mathrm{pmol} . \mathrm{L}^{-1}$ and a median of $0.23 \mathrm{pmol} . \mathrm{L}^{-1}$ for the 241

341 samples analyzed. All vertical $\mathrm{MeHg}_{\mathrm{T}}$ profiles exhibited roughly the same pattern with low 342 concentrations in the surface mixed layer $(0-100 \mathrm{~m}$ ) (except at three stations $\mathrm{N}-03, \mathrm{~N}-09$ and $\mathrm{N}$ 34318 , where surface maxima were observed), and increasing concentrations with depth to an 344 intermediate maximum. Deeper in the water column, $\mathrm{MeHg}_{\mathrm{T}}$ concentrations decreased or remained relatively constant (Fig. 5a). Lowest values 2 pmol. $L^{-1}$ ) were observed within the upper $100 \mathrm{~m}$ of the PFZ (Stns. N-07, 08, 11, 12, 13 and 15) (Fig. 6). Low mean $\mathrm{MeHg}_{\mathrm{T}}$ concentrations were also associated with AAIW, which $d$ red significantly from AABW 
( $\mathrm{p}<0.05$, Table 2). Maximum $\mathrm{MeHg}_{\mathrm{T}}$ concentrations at each station were systematically observed

349 within the oxygen minimum zone (the $\mathrm{MeHg}_{\mathrm{T}}$ vs $\mathrm{AOU}$ relationship is statistically significant 350 with $\mathrm{p}<0.001, \mathrm{R}^{2}=0.722, \mathrm{n}=236$ ) as usually found in the oceanic water $\mathrm{c}$ ns (Mason and

351 Fitzgerald, 1990, Cossa et al., 1997, 2009; Sunderland et al., 2009; Heimbürger et al., 2010). The

$352 \mathrm{MeHg}_{\mathrm{T}}$ maximum followed the upper part of CDW as it shoaled $\mathrm{m} 2000 \mathrm{~m}$ in the STZ and 353 SAZ to outcrop at the sea surface in the AZ (Fig. 6), here the highest values were observed 354 (0.81 and 0.86 pmol.L $\mathrm{L}^{-1}$ at Stns. N-05 and N-08, respectively) (Fig. 5b). The proportion of $\mathrm{Hg}_{\mathrm{T}}$ as methylated species was lower than $5 \%$ in the surface waters, around $50 \%$ in deep waters below $1000 \mathrm{~m}$, peaking up to $78 \%$ in the low oxygen waters south of the SPF (Figs. 2c and 5c). These proportions in intermediate and deep waters are relatively elevated compared to proportions compiled from different parts of the World Ocean, which vary from a few percent in the North Atlantic up to $35 \%$ in the Mediterranean (see Table 10-1 in Mason and Gill, 2005). Note that the $\mathrm{MeHg}_{\mathrm{T}}$ concentrations remain relatively high in deep waters, suggesting a high stability of methylated $\mathrm{Hg}$ when these molecules are out of the influence of light.

\subsection{DGH g distribution in the SO}

DGHg concentrations ranged between $<0.01$ to 0.59 pmol. $\mathrm{L}^{-1}$ with an arithmetic mean of 0.19 pmol. $\mathrm{L}^{-1}$, a standard deviation of $0.11 \mathrm{pmol} \mathrm{\textrm {L } ^ { - 1 }}$ and a median of $0.21 \mathrm{pmol} . \mathrm{L}^{-1}$ for the 58 samples analyzed. The vertical DGHg distributions exhibited a pattern with larger variations in the upper $200 \mathrm{~m}$ (from <0.01 to $0.59 \mathrm{pmol} . \mathrm{L}^{-1}$ ), and more homogeneous concentrations at depth $\left(0.20-0.31\right.$ pmol.. $\left.{ }^{-1}\right)$ (Fig. 7). Highest DGHg concentrations were measured etween 100 and $200 \mathrm{~m}$ at stations south of the SPF (Stns. N-04 and N-07, Fig. 7). According to the $\mathrm{MeHg}_{\mathrm{T}}$ profiles (Fig. 5a) it is unlikely that this DGHg consists of DMHg; more probably DGHg is mostly present as $\mathrm{Hg}^{0}$, the end-product of demethylation. The depth of the mixed layer at these two stations is $100 \mathrm{~m}$, suggesting an intense outgassing of $\mathrm{Hg}^{0}$ from the well-mixed layer to the atmosphere and its accumulation below. At lower latitudes (Stns. N-17, N-20 and N-23), very low DGHg concentrations were observed in the top $200 \mathrm{~m}$ as observed for $\mathrm{Hg}_{\mathrm{R}}$, While part of the DGHg may be made up of DMHg in intermediate and deep waters (Mason and Gill, 2005), DGHg constituted a high proportion of $\mathrm{Hg}_{\mathrm{R}}$ (up to 90\%) between 0 and $200 \mathrm{~m}$, where $\mathrm{DMHg}$ is supposed to be absent or negligible. The DGHg mean concentrations did not differ significantly with water masses (Tables 1 and 2). 


\subsection{Mercury speciation in coastal sea ice}

379 The most striking feature of the $\mathrm{Hg}_{\mathrm{T}}$ data collected at the shallow coastal station near Casey

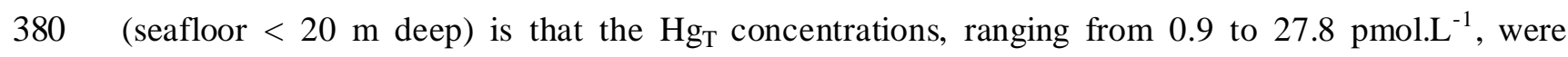
381 one order of magnitude higher than those measured in open sea waters. Figure 8 illustrates the 382 distribution of $\mathrm{Hg}_{\mathrm{T}}$ found in the snow and sea ice (Fig. 8a-e) and in seawater below the ice (Fig. 383 8f-j). Detailed data, with sack-hole brine values, are given as supplementary information in the 384 Web appendix 2. High $\mathrm{Hg}_{\mathrm{T}}$ concentrations occurred in snow, sack-hole brine and seawater, 385 compared to bulk sea ice (Web appendix 2). $\mathrm{Hg}_{\mathrm{T}}$ distributions in sea ice were generally ' $\mathrm{C}$ '386 shaped, with higher concentrations in the top and bott parts of the sea ice cover (Fig. 8). The 387 ' $C$ '-shape profile has been described in the case of sea ice bulk salinity in many other field 388 studies (e.g. Nakawo and Sinha, 1981; Weeks and Ackley, 1986; Eicken, 1992) as a result of the 389 combined effects of initial salt entrapment, brine drainage and brine expulsion. Such tributions 390 have also been previously reported for other trace metals in Antarctic pack ice (Lannuzel et al., 391 2010). Variability between sampling days (Fig. 8) may, however, simply reflect the spatial 392 heterogeneity of the area (ice cores were separated by up to $10 \mathrm{~m}$ on different sampling days). 393 The overall $\mathrm{Hg}_{\mathrm{R}}$ distribution (Web appendix 2) follows the same patter as $\mathrm{Hg}_{\mathrm{T}}$, with variable 394 proportion 10 to $100 \%$ of the $\mathrm{Hg}_{\mathrm{T}}$ as $\mathrm{Hg}_{\mathrm{R}}$. Highest $\mathrm{Hg}_{\mathrm{R}} / \mathrm{Hg}_{\mathrm{T}}$ ratios were often found within snow 395 and brine (except on the 17 November samples, Web appendix 2). In contrast to $\mathrm{Hg}_{\mathrm{T}}$ and $\mathrm{Hg}_{\mathrm{R}}$, $396 \mathrm{MeHg}_{\mathrm{T}}$ concentrations were in the range of those encountered in open ocean waters, remaining 397 below 0.45 pmol. $\mathrm{L}^{-1}$. The $\mathrm{MeHg}_{\mathrm{T}}$ vertical profile through the "snow-sea ice-seawater" continuum 398 was complex (Fig. 8). A peak concentration was observed at the base of the sea ice, where high 399 organic matter concentration and autotrophic activity present (Web appendix 2; Fig. 8). In 400 snow samples relatively high $\mathrm{MeHg}_{\mathrm{T}}$ levels were found $\left(0.34 \mathrm{pmol} \mathrm{L}{ }^{-1}\right)$. This complex structure 401 suggests different sources of methylmercury, including atmosphere, marine water and in situ 402 methylation. The results of a Principal Component Analysis performed on salinity, particulate 403 organic carbon (POC), Chla, $\mathrm{Hg}_{\mathrm{T}}, \mathrm{Hg}_{\mathrm{R}}$ and $\mathrm{MeHg}_{\mathrm{T}}$ in the sea ice brine and seawater indicate that $40474 \%$ of the whole variability of these parameters is explained by two factors and that $\mathrm{Hg}_{\mathrm{T}}$ and $405 \mathrm{Hg}_{\mathrm{R}}$ covaried with salinity, whereas $\mathrm{MeHg}_{\mathrm{T}}$ covaried with POC and Chla (Web appendix 3). This 406 supports the ideas that in sea ice environment the ino nic $\mathrm{Hg}$ distribution is governed by sea 407 salt exclusion and methylated mercury distribution is erned by biological processes. 
The chemistry of $\mathrm{Hg}$ in ocean water is more complex than that of any other trace 411 elements. Many chemical reactions occur between the deposition of atmospheric $\mathrm{Hg}$ on the ocean 412 surface and the burial of $\mathrm{Hg}$ in the sediment and/or bioaccumulation in the food chain. In the 413 dissolved phase $\mathrm{Hg}$ may exist as $\mathrm{Hg}^{0}$ or, $\mathrm{Hg}^{\mathrm{II}}$ bound to inorganic (mainly chloride or sulfide) or 414 organic ligands (mainly methyl or thiol groups) (Mason and Gill, 2005). Methylated Hg species $415\left(\mathrm{MeHg}_{\mathrm{T}}\right)$ comprise neutral $\mathrm{DMHg}$ and $\mathrm{MMHg}^{+}$bound chiefly to chloride, sulfide or thiol. 416 Mercury speciation performed on board and in the labor $y$, allowed us to differentiate 417 operationally defined species, namely $\mathrm{DGHg}$, which includes $\mathrm{Hg}^{0}$ and $\mathrm{DMHg}, \mathrm{MeHg}_{\mathrm{T}}$ which 418 includes $\mathrm{MMHg}$ and $\mathrm{DMHg}$, and the labile $\mathrm{Hg}$, so-called reactive mercury $\left(\mathrm{Hg}_{\mathrm{R}}\right)$, which is 419 assumed to represent both $\mathrm{Hg}^{0}$ and $\mathrm{Hg}^{\mathrm{II}}$, associated with inorganic or very weak organic complexing 420 agents (Lamborg et al., 2003). Mercury transformations known to occur in the oceanic waters and at 421 the MBL include (i) redox reactions between $\mathrm{Hg}^{\mathrm{II}}$ and $\mathrm{Hg}^{0}$, (ii) methylation-demethylation, and (iii) 422 heterogeneous reactions, such as the sorption of charged species and the solid solution of neutral 423 species. All these chemical forms are intricately linked togeth through the divalent pool $\left(\mathrm{Hg}^{\mathrm{II}}\right)$ 424 and are often catalyzed by biological activity, especially $\mathrm{Hg}$ ethylation (Mason and Gill, 2005; 425 Heimbürger et al., 2010). A schematic view of the ocea $\mathrm{Hg}$ cycle can be summarized as follows. 426 Elemental mercury is oxidized at the MBL and deposited onto the sea surface via dry or wet 427 processes. These $\mathrm{Hg}^{\mathrm{II}}$ species are either reduced again (and re-emitted in the troposphere), or 428 bound to mineral or organic ligands, and/or sorbed onto phytoplankton within the photic zone. 429 Inorganic $\mathrm{Hg}$ transported downward attached to particles (mainly biogenic), can be 430 biomethylated in the water column with rates depending on the type of microbial ecosystem 431 associated with phytoplankton degradation (Heimbürger al., 2010). Conversely, biological and 432 photochemical demethylations (with $\mathrm{Hg}^{0}$ as an end product) occurs concurrently, so that 433 methylmercury concentrations reflect the net effect of methylation-demethylation. Although $\mathrm{Hg}$ 434 sinking with large particles to the sediment may be in ved in early diagenetic transformations 435 that take place at the ocean-sediment interface of the abyssal sediments (Gobeil et al., 1999), 436 these sediments constitute the final sink for $\mathrm{Hg}$ in the open ocean environment. 
438 According to a study in a coastal region of Antarctica (McMurdo/Ross Sea region) the $\mathrm{Hg}_{\mathrm{T}}$ in 439 surface snow is greatly enhanced at the sea ice edge a ent to the freezing ocean surface 440 (Brooks et al., 2008). While Mount Erebus volcano and he Antarctic base of 1200 people may 441 influence higher $\mathrm{Hg}$ ocean surface concentrations in the McMurdo region, the Casey station area 442 is only affected by a small human community and Adelie penguin colonies. Note that the $\mathrm{Hg}$ 443 concentrations we found in fast ice near Casey station (0.9-28.4 pmol. $\mathrm{L}^{-1}$, Web appendix 2) are 444 also elevated and three orders of magnitude above the ncentration range measured in surface 445 water in the SO. Whilst data from Brooks et al. (2008) and our data point towards an enrichment 446 in $\mathrm{Hg}$ in the snow pack, one can expect that a large part of the $\mathrm{Hg}$ deposited with snow on the 447 continent and on the sea ice is rapidly re-emitted because of $\mathrm{Hg}^{\mathrm{II}}$ photo-reduction, as it has been 448 suggested for the Arctic environment (Poulain et al., 4). However, the post-depositional fate 449 of $\mathrm{Hg}$ in snow has not yet been assessed near the ice edge, where most of the oxidation of $\mathrm{Hg}^{0}$ takes place due to halogens released from the sea. The magnitude of the $\mathrm{Hg}$ re-emission is still under debate (Larose et al., 2010). Bargagli et al. (2005) found that whilst a large proportion of $452 \mathrm{Hg}$ deposited in surface snow during austral spring MDEs can be efficiently and rapidly recycled 453 back to the atmosphere by photoreduction processes, this process cannot compensate for the total 454 deposition. Dommergue et al. (2010) also concluded that, due to the high reactivity of $\mathrm{Hg}^{0}$ and 455 the presence of $\mathrm{Hg}^{\mathrm{II}}$ from late winter to summer, there is likely to be an portant net input of 456 atmospheric $\mathrm{Hg}$ onto Antarctic surfaces. Conversely, Chaulk et al. (2011) recently concluded, 457 from a study on mercury transport across the ocean-sea-ice-atmosphere interface in the Arctic 458 Ocean, that the impact of MDEs on $\mathrm{Hg}$ concentrations in the sea-ice is insignificant. Climatic 459 differences may be at the origin of this discrepancy. eed, high precipitation rate does occur

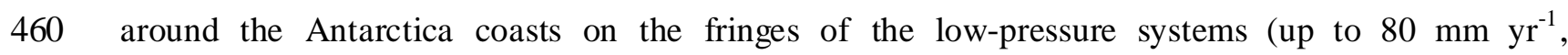
461 http://www.antarctica.ac.uk/met/climate/wmc/). Our observations of high $\mathrm{Hg}$ values in snow 462 (Fig. 8d) support the idea of a net atmospheric deposition a the sea ice edge, where halogen 463 oxidation is favoured. The low salinity and warm temperature of the upper sea ice cover implies 464 melting snow events, which also suggest that atmospheric $\mathrm{Hg}$ deposition may contribute to the 465 higher concentration of $\mathrm{Hg}_{\mathrm{T}}$ in the top most part of the ice cover (Fig. 8). In addition, when the 466 sea ice extent increases in autumn/winter in the SZ, the sea surface is protected from the UV, 467 resulting in decreased $\mathrm{Hg}^{\mathrm{II}}$ photoreduction, and allowing the build-up of $\mathrm{Hg}$-enriched surface 468 waters during winter months. This process may concur to explain the elevated $\mathrm{Hg}_{\mathrm{T}}$ and $\mathrm{Hg}_{\mathrm{R}}$ 
concentrations we observed in under-ice seawater during the Casey field work and further in the SZ during GeOTRACES cruise (Figs. 3 and 4). The build-up of $\mathrm{Hg}$ enriched surface waters under the ice is (i) supported by the low value of the $\mathrm{DGHg} / \mathrm{Hg}_{\mathrm{R}}$ ratios in surface samples $(<30 \%$ in the $\mathrm{SZ}$ at the ice edge), which suggests that $\mathrm{Hg}_{\mathrm{R}}$ is constituted mainly of oxidized $\mathrm{Hg}$ and, (ii) consistent with the presence of dissolved organic ligands exuding from the massive primary production at the basal ice into surface waters (see high POC and Chla, Fig. 8g and h, and web appendix 2). Mercury enrichment from sedimentary sources even in the coastal zone seems unlikely at this time of the year, since, despite the shallow bathymetry, the seawater profiles o not show contribution from sediment resuspension (Fig. 8 and Web appendix 2).

However, such high concentrations in surface waters were also found for iron and other trace elements during the Casey time-series study (van der Merwe et al., in press), metals ich have no locally enhanced atmospheric sources. The under-ice seawater profiles show lower $\mathrm{Hg}_{\mathrm{T}}$ concentrations with increasing depth and sampling days (Fig. 8). This spatial and temporal distribution suggests a seeding of $\mathrm{Hg}_{\mathrm{T}}$ from melting ice. This process is most likely initiated by the warming of the upper ice cover (van der Merwe et a in press), followed by gravity-driven brine movement and density-driven convection mechanisms at the ice/water interface (brine salinity > seawater salinity). This interpretation agrees with some of the conclusions by Chaulk et al. (2011), who proposed that $\mathrm{Hg}$ in the sea-ice Arctic environment is primarily driven by particle enrichment and salt rejection during the sea ice formation. Our results do suggest an exclusion of $\mathrm{Hg}$ from ice and its enrichment in brine by the positive relationships found between $\mathrm{Hg}$ and salinity in ice and brine $\left(\mathrm{R}^{2}=0.69\right.$ and 0.48 , for $\mathrm{Hg}_{\mathrm{T}}$ and $\mathrm{Hg}_{\mathrm{R}}$, respectively), but do not support a role for particles, since we filtered our snow, ice and brine samples.

In summary, we suggest that multiple processes are able to enrich $\mathrm{Hg}$ in the surface waters in the seasonal ice zone: (i) a net atmospheric $\mathrm{Hg}$ deposition on ice-free surface water near the ice edge, (ii) the shielding from photoreduction under the ice-cover during winter months, (iii) massive algal production at basal sea ice during spring and summer, and (iv), the $\mathrm{Hg}$ enrichment in brine during sea ice formation. These processes result in build-up of Hg-enriched surface waters during winter months and its subsequent downward transfer with the AABW. The hypothesis of a $\mathrm{Hg}$ enrichment in $\mathrm{AABW}$ is supported by the slightly higher $\mathrm{Hg}_{\mathrm{R}}$ mean concentration compared to CDW and AAIW, and the slightly higher $\mathrm{Hg}_{\mathrm{T}}$ mean concentration compared to AAIW (Tables 1 and 2). The relative contribution of the various processes may vary seasonally and would, 
therefore, require further investigations. Indeed in the present observations, we might have some decoupling in the processes between the SZ observations during the SR3 GeOTRACES transect made in autumn (when sea ice is formed) and Casey station observations made during the Austral spring (when sea ice melts).

Regarding methylmercury in the sea ice environment, the complex distribution of $\mathrm{MeHg}_{\mathrm{T}}$ distribution in the coastal "snow-sea ice-seawater" continuum (Fig. 8) favours a multiple source system, consistent with the recent findings by Larose al. (2010) who conclude that MMHg is supplied to Arctic environments by various pathways that occur simultaneously. Our observations of high $\mathrm{MeHg}_{\mathrm{T}}$ in snow, seawater and basal sea ice (Fig. 8c) suggest that, oceanic and atmospheric methylmercury sources and $\mathrm{Hg}$ methylation at the ice-water interface (where sea ice algae are abundant as revealed by the high Chla and POC content) are dominant processes (see section 4.6). Abiotic methylation may occur in th atmosphere (Gardfeldt et al., 2003) as a result of the presence of acetate as methyl donor and $\mathrm{Hg}^{\mathrm{II}}$ in the atmospheric aqueous phase. Aerobic microbiological and abiotic (via DMSP by-products) methylation at the ice pack interfaces are both possible as proposed by Larose et 1. (2010) for the snowpack of the Svalbard Archipelago.

\subsection{Mercury speciation in SO waters}

Although $\mathrm{Hg}$ is considered as a reactive element with a short residence time in seawater (similar to $\mathrm{Pb}$ ), its vertical distribution in the ocea is more complex than simple surface enrichment and low concentrations at depth, reflecting an atmospheric source and particle removal, respectively. Indeed, that fact that several species participate in the oceanic organic matter cycle of generation and mineralization, results in distributions characterized by surface depletion and elevated concentrations at depth in the egeneration zone. The vertical distributions of $\mathrm{Hg}_{\mathrm{R}}, \mathrm{MeHg}_{\mathrm{T}}$, and DGHg that we found in SO waters are rather "classical", corresponding to the $\mathrm{Hg}$ cycle described above. Indeed, the $\mathrm{Hg}$ species profiles we recorded in the $\mathrm{SO}$ are consistent with the early or refined general model (e.g., Mason and Fitzgerald, 1990; Sunderland et al., 2009), according to which $\mathrm{Hg}$ enters the ocean s inorganic species from the atmosphere, is scavenged by particles that sink from the euphotic zone and re-supply $\mathrm{Hg}$ at depth during organic matter degradation, and that serve as a substrate for methylating bacteria. 
529 Whereas, $\mathrm{Hg}_{\mathrm{R}}$ vertical profiles (Fig. 4) reflect both dry $\mathrm{RGHg}$ and $\mathrm{t} \mathrm{Hg}^{\mathrm{II}}$ deposition on the sea 530 surface, and organic matter regeneration processes that mobilize $\mathrm{H}$ from biogenic particles, $531 \mathrm{MeHg}_{\mathrm{T}}$ concentrations increase downward (Fig. 5) as a result of methylation-demethylation in 532 the water column with net methylation at depth. The $\mathrm{DGHg} / \mathrm{Hg}_{\mathrm{R}}$ ratios in surface waters (always $533<50 \%$ ) suggest a significant supply of $\mathrm{Hg}^{\mathrm{II}}$ via atmospheric deposition. $\mathrm{MeHg} / \mathrm{Hg}_{\mathrm{T}}$ ratios, 534 considered as a proxy for net methylation for the water column as well as for sediment 535 (Fitzgerald et al. 2007), were high in the sub-thermocline hypoxic zone (50\%) and up to $78 \%$ in 536 the sub-thermocline hypoxic zone at Stn. N-05 (Fig. 5c). Malcolm et al. (2004) measured 537 methylation in the thermocline waters of the North Pacific Ocean, and sub-thermocline marine 538 waters enriched with nutrients that stimulated the bacterial community were found to favour $\mathrm{Hg}$ 539 methylation. In the Southern Ocean, the phytoplankton ass and export of organic matter 540 from the photic zone is known to be high in AZ and SZ (Sullivan et al., 1993; Sokolov, 2008) and 541 should provide substantial inorganic $\mathrm{Hg}$ at depth with the sinking and regeneration of organic 542 particles. Thus, we hypothesize that the hypoxic zone $\mathrm{f}$ the $\mathrm{AZ}$ of the SO is an area of strong net $543 \mathrm{Hg}$ methylation supported by substantial organic matter regeneration and a large inorganic $\mathrm{Hg}$ 544 substrate supply.

545 It could be argued that the $\mathrm{MeHg}_{\mathrm{T}}$ distribution along the SR3 GEOTRACES transect is just the trace 546 of methylated mercury species advected South with the W, and subsequently upwelled as $547 \mathrm{CDW}$ at the Antarctic divergence. Indeed, the distributions of oxygen and $\mathrm{MeHg}_{\mathrm{T}}$ are largely 548 mirror images of each other, with maximum values of $\mathrm{MeHg}_{\mathrm{T}}$ observed in the oxygen minimum 549 of the upper CDW. The distribution of high $\mathrm{MeHg}_{\mathrm{T}}$ waters reflects, in part, the shoaling and 550 poleward spreading of upper CDW. However, advection and mixing alone cannot explain the 551 increase in $\mathrm{MeHg}_{\mathrm{T}}$ concentrations to the south. $\mathrm{MeHg}_{\mathrm{T}}$ concentrations were high for water layers 552 with potential density ranging between 27.50 and 27.75 , and reached maximal values between $55358^{\circ}-63^{\circ} \mathrm{S}$, suggesting there must an in situ source of $\mathrm{MeHg}_{\mathrm{T}}$ at high southern latitudes (Web 554 appendix 4). The AOU distribution, a proxy for heterotrophic activity, showed the highest values 555 for the same isopycnals at the same latitudes (Web app ix 5). This supports the idea of a 556 bacterial methylation of inorganic $\mathrm{Hg}$ within the hypox part of the oceanic water column, most 557 significantly in the $\mathrm{AZ}$ and $\mathrm{SZ}$. In addition, the lower concentration of $\mathrm{MeHg}_{\mathrm{T}}$ observed in the 558 vicinity of the Antarctic continent (Fig. 6) precludes the significant influence of $\mathrm{MeHg}_{\mathrm{T}}$ inputs 559 from shelf sediments in the central part of the SZ. Th overall correlation between $\mathrm{MeHg}_{\mathrm{T}}$ and 
AOU along the SR3 transect is highly significant $(\mathrm{p}<0.001)$ with an equation: $\mathrm{MeHg}_{\mathrm{T}}(\mathrm{pmol})=$ $0.0031 * \mathrm{AOU}(\mu \mathrm{mol})+0.119\left(\mathrm{R}^{2}=0.722, \mathrm{n}=236\right)$. The regression coefficient is of the same order of magnitude as that calculated for the first $600 \mathrm{~m}$ of the Mediterranean Sea (Cossa et al., 2009; Heimbürger et al., 2010) and North Pacific (recalculated from the data of figure 4 by Sunderland et al. (2009)), i.e., $\sim 0.004\left(\mathrm{pmol}_{\mathrm{MeHg}} / \mu \mathrm{mol}_{\mathrm{AOU}}\right)$. Calculated for each station individually, 20 out of a possibility of $27 \mathrm{MeHgT}$ vs AOU relationships were significant $(\mathrm{p}<0.10)$, with 14 highly significant $(\mathrm{p}<0.01)$ (Web appendix 6). Regression coefficients varied appreciably from one station to another $\left(0.0016-0.0051 \mathrm{pmol}_{\mathrm{MeHg}^{\mathrm{T}}} / \mu \mathrm{mol}_{\mathrm{AOU}}\right)$. Low regression coefficients were observed in the SAZ north of the SAF and high values were observed in the AZ and SZ (web appendix 6). The regression coefficient of the $\mathrm{MeHg}_{\mathrm{T}}$ vs AOU relationships has been interpreted as a proxy for the in situ methylation capacity of the water column per unit of oxygen consumed (Cossa et al., 2009; Heimbürger et al., 2010), and therefore, reflects in some way the bioavailability of $\mathrm{Hg}$ for methylating bacteria. Thus, the $\mathrm{Hg}$ bioavail ity would be favored in the $\mathrm{AZ}$ and $\mathrm{SZ}$ of the $\mathrm{SO}$. The enhanced $\mathrm{Hg}$ de tion and the unique $\mathrm{Hg}$ cycle within the sea ice zone may be responsible for the enhanced $\mathrm{Hg}$ bioavailability. The $\mathrm{Hg}^{\mathrm{II}}$ fraction of the $\mathrm{Hg}_{\mathrm{R}}$, with concentrations several times higher in the $\mathrm{SZ}$ than elsewhere, is a good candidate group of species for the bioavailability for methylation. If we extrapolate the observations we made concerning the area under the ice on a coastal site (see above, section 5.1.) to the edge of free sea ice development, a building up of $\mathrm{Hg}$ enriched water under the ice in SZ during the polar night may be assumed. In spring and summer with the opening of the pack due to ice melting and the development of phytoplanktonic blooms, inorganic $\mathrm{Hg}$ is sorbed and/or taken $\mathrm{u}$ by phytoplankton cells provided by the large primary production in the SZ (Sullivan et al., 1993; Sokolov, 2008) and can undergo methylation in the euphotic and/or aphotic zone as proposed by Heimbürger et al. (2010) for the open Mediterranean. This inte tation is supported by the early results from a single $0-200 \mathrm{~m}$ profile in the SO (53'30'S; $\left.9^{\circ} 00^{\prime} \mathrm{E}\right)$, where both $\mathrm{MHg}$ and DMHg have been determined with sub-surface maxima (0.1-0.2 pmol. $\mathrm{L}^{-1}$ ) (Pongratz and Heumann, 1998). Furthermore, the production of methylated $\mathrm{Hg}$ by marine polar bacteria has been demonstrated by the same authors in a subsequent study (Pongratz and Heumann, 1999).

\subsection{The role of the $\mathrm{SO}$ in the global $\mathrm{Hg}$ cycle}

Mercury is thought to enter the ocean mainly via atmospheric deposition. Even if the upper ocean is not in a steady state with the atmosphere, th surface water $\operatorname{Hg}_{\mathrm{T}}$ concentrations reflect 
591 the magnitude of the atmospheric $\mathrm{Hg}$ deposition (Mason nd Gill, 2005). In spite of the removal processes, namely scavenging and evasion, deep water masses previously in contact with the atmosphere would contain the trace of the atmospheric eposition received when it was at the surface. This has been proposed for the Atlantic ocean water column, where a major portion of the deep water of the World Ocean is formed by the deep convection of surface waters (Mason et al., 1998; Cossa et al., 2004). Indeed, the North Atlantic surface waters sink in the Labrador and Norwegian Seas to form North Atlantic Deep Water (NADW) (Rahmstorf, 2002). This water mass travels South and reaches the SO to form the Circ olar Deep Waters (CDW). In the $\mathrm{NADW}$ at $65^{\circ} \mathrm{N}(1000 \mathrm{~m})$, Mason et al. (1998) measured $\mathrm{Hg}_{\mathrm{T}}$ concentrations higher than 2 pmol $\mathrm{L}^{-1}$, whereas Cossa et al. (2004) found slightly lower concentrations $\left(\sim 1.7 \mathrm{pmol} \mathrm{L}^{-1}\right)$ in the core of

601 the NADW at a lower latitude $\left(48^{\circ} \mathrm{N}\right)$ and at greater depth $(2000 \mathrm{~m})$. Traveling South NADW 602 does not seem to change its $\mathrm{Hg}$ concentration markedly, since a concentration of $1.8 \mathrm{pmol} \mathrm{L}^{-1}$ was 603 recorded by Mason and Sullivan (1999) in the South Atlanti at $\sim 16^{\circ} \mathrm{S}$. Our present $\mathrm{Hg}_{\mathrm{T}}$ measurements made in the CDW, collected at depths ranging from 500 to $3000 \mathrm{~m}$, far to the East $\left(140^{\circ} \mathrm{E}\right)$ and South $\left(46-62^{\circ} \mathrm{S}\right)$ are lower, $1.2 \pm 0.3 \mathrm{pmol} \mathrm{L}^{-1}$ (Table 1), than all the measurements made in the NADW until now. This 1.8 to $1.2 \mathrm{pmol}^{-1}$ concentration decrease may be attributable to $\mathrm{Hg}$ scavenging during the transit of this water mass southward through the Atlantic and eastward in the SO. From the $\mathrm{Hg}_{\mathrm{R}}$ distribution in deep waters along the SR3 transect (Fig. 4), it appears that labile $\mathrm{Hg}$ concentrations tend to be slightly higher north of $53^{\circ} \mathrm{S}$ than south, which 611 their transit poleward. As shown by the $\mathrm{Hg}_{\mathrm{T}}$ distribution on the transect (Fig. 3), it is clear that 612 the $\mathrm{Hg}$ originating from the atmosphere in the North Atlantic and brought to the southern 613 hemisphere with NADW is not responsible for the $\mathrm{Hg}_{\mathrm{T}}$ enrichment south of the SAF observed on 614 the SR3 transect. More likely, the surface distribution with high concentrations at the 615 southernmost stations suggests an $\mathrm{Hg}$ source in the surface water near the ice edge (Fig. 3). These 616 high surface $\mathrm{Hg}$ concentrations (> 2 pmol. $\mathrm{L}^{-1}$ ) were found under sea ice broken by the research 617 vessel (Stns. N-02 and N-03) and at the SPF (St. N-08). The net atmospheric Hg deposition is a 618 likely source for this enrichment. Further $\mathrm{Hg}$ transfer to the AABW would be favored by the sea 619 ice formation (excluding $\mathrm{Hg}$ with salts), and during the ice melting, which would seed the water 620 column with $\mathrm{Hg}$ in the SZ. Based on a difference of mea $\mathrm{Hg}_{\mathrm{T}}$ concentrations of $0.16 \mathrm{pmol} \mathrm{L} \mathrm{L}^{-1}$ 621 between $\mathrm{AABW}$ and CDW (Table 1) and a flux of AABW sinking around the SO of $5.4 \pm 1.7 \mathrm{~Sv}$ 
622 (Orsi et al. 2002), a total $\mathrm{Hg}$ flux from sea surface to deep ocean of $27 \mathrm{kmol}_{\mathrm{yr}}{ }^{-1}$ during sea ice 623 formation can be derived. The effect of $\mathrm{Hg}$ exclusion during ice formation seems insufficient for 624 explaining such flux since an increase of 0.1 salinity unit would only generate a $0.02 \mathrm{pmol} \mathrm{L}^{-1}$ 625 change in $\mathrm{Hg}_{\mathrm{T}}$ concentration $\left(\mathrm{Hg}_{\mathrm{Tpmol} . \mathrm{L}}{ }^{-1}=0.21^{*} \mathrm{Sal}+3.6, \mathrm{R}^{2}=0.69\right)$, i.e., $\sim 3.5 \mathrm{kmol} . \mathrm{yr}^{-1}$ for 5.4

626 Sv. Net atmospheric $\mathrm{Hg}$ deposition near the sea ice edge would be the additional source.

627 In contrast with AABW, AAIW formed north of the Antarctic divergence in the PFZ show a 628 slight $\mathrm{Hg}$ depletion compared to CDW (Tables 1 and 2). s may be the result of $\mathrm{Hg}$ removal 629 processes in surface waters, namely $\mathrm{Hg}^{\mathrm{II}}$ reduction, which leads to $\mathrm{Hg}^{0}$ evasion to the 630 atmosphere, and the $\mathrm{Hg}^{\mathrm{II}}$ sorption onto phytoplankton, which leads to $\mathrm{Hg}$ sinking with particles 631 exported to the ocean floor. From this first survey of $\mathrm{Hg}$ distribution and speciation, we can 632 reasonably speculate that a part of $\mathrm{Hg}$ removed from the SO surface north of the PFZ may be 633 atmospherically transported south, with high-altitude circulation, transferred in the lower 634 troposphere with the polar cell circulation, then carried north to the MBL with katabatic winds. 635 Near the sea ice edge atmospheric $\mathrm{Hg}$ undergoes oxidation notably during MDE, to be reinjected 636 into the deep ocean in the SZ due to the sea ice formation-melting cycle.

637 In summary, our findings, placed within the context of global oceanic $\mathrm{Hg}_{\mathrm{T}}$ distribution, imply a 638 (i) removal of $\mathrm{Hg}$ by settling particles from NADW on its way to the Southern Ocean, (ii) an 639 evasion of $\mathrm{Hg}$ from the sea surface North of the convergence zone, and (iii) an Hg enrichment of 640 the waters in the SZ, which spread off with the AABW t ling northward. This Hg enrichment 641 would have its source in the MBL south of the SACCF, near the ice-edge (within the SZ) and 642 would be transferred to depth by sinking of dense wate formed by brine rejection during sea ice 643 formation. Further confirmation of differences in $\mathrm{Hg} \mathrm{c}$ entration between water types is 644 necessary before concluding to a model where the $\mathrm{Hg}$ atmospheric injection and redistribution 645 mechanisms acting in the SO lead to a transfer north w AABW of Hg enriched waters.

\section{CONCLUSIONS}

With $50 \%$ of the values (the interquartile range) lying between 1.1 and 1.5 pmol. $\mathrm{L}^{-1}, \mathrm{Hg}_{\mathrm{T}}$ concentrations in the water samples collected along the SR3 GEOTRACES transect between the 
652 Cossa et al., 2004; Cossa et al., 2009; Sunderland et 2009). Nevertheless, some unique 653 features in the $\mathrm{Hg}$ species distributions are clearly noticeable. Firstly, the concentration of $\mathrm{Hg}_{\mathrm{T}}$ 654 and $\mathrm{Hg}_{\mathrm{R}}$ in surface waters increases poleward, reaching values $>2 \mathrm{pmol} \cdot \mathrm{L}^{-1}$ in the $\mathrm{AZ}$ and $\mathrm{SZ}$, 655 and a maximum of 44.4 pmol. $\mathrm{L}^{-1}$ below the coastal sea ice. Secondly, $\mathrm{Hg}_{\mathrm{T}}, \mathrm{Hg}_{\mathrm{R}}$ and $\mathrm{MeHg}_{\mathrm{T}}$ concentrations tend to be higher in the AABW compared the AAIW, and thirdly, high 657 proportions of methylated mercury $(50 \%)$ occur in the hypoxic part of the water column, up to $65878 \%$ in AZ. These distribution characteristics suggest ree main drivers of the SO Hg cycle: (i) a 659 net $\mathrm{Hg}$ input to the ocean surface near the Antarctic c nent from an atmospheric source, (ii) a 660 role of sea ice formation in the transfer of $\mathrm{Hg}$ enriched waters to depth, and (iii) a substantial net 661 methylation of $\mathrm{Hg}$ south of the SPF as a result of the co-location of enhanced atmospheric $\mathrm{Hg}^{\mathrm{II}}$ 662 input and the bacterial decomposition of organic matte produced by intense phytoplankton 663 blooms, which are superimposed with the advection of $\mathrm{m}$ ylmercury-enriched deep water by 664 the upwelling at the Antarctic divergence.

665 High $\mathrm{Hg}$ concentrations have been observed in Antarctic biota, despite the remoteness from 666 anthropogenic sources (Bargagli, 2008; Bargagli et al., 2005). Birds from the SO have very large $667 \mathrm{Hg}$ concentrations (up to $680 \mu \mathrm{g} \mathrm{g}^{-1}$, wet weight) (Hindell et al., 1999), suggesting a huge 668 bioaccumulation, surprising a priori for a remote environment. In order to be biomagnified in 669 fish and sea-birds, inorganic $\mathrm{Hg}$ must first be converted to methylm ury and bioconcentrated 670 by phyto- and zoo-plankton. Our first systematic measurement of $\mathrm{MeHg}_{\mathrm{T}}$ in Antarctic waters 671 suggests that a unique combination of atmosphere, ocean and sea ice processes can explain the 672 elevated concentrations of methylmercury observed in the AZ and SZ of the remote Antarctic 673 waters (including the sea ice zone), and therefore, th high bioaccumulation of $\mathrm{Hg}$ in pelagic 674 seabirds, marine mammals and top predators. Halogens released to the atmosphe during sea ice 675 formation facilitate the oxidation and deposition of atmospheric $\mathrm{Hg}$; extensive phytoplankton 676 blooms in the same region produce organic particles that scavenge inorganic $\mathrm{Hg}$ from the water 677 column and sink to supply organic matter and inorganic $\mathrm{Hg}$ as a substrate for methylating 678 bacteria in the hypoxic zone; and the upwelling of wat that is low in oxygen and rich in $\mathrm{MeHg}_{\mathrm{T}}$ 679 (both characteristics resulting from bacterial activity during the long transit time of the upper $680 \mathrm{CDW}$ ) further enhances $\mathrm{MeHg}_{\mathrm{T}}$ concentrations. As a result, the remote Antarctic waters exhibit 681 some of the highest $\mathrm{MeHg}_{\mathrm{T}}$ concentrations observed in the open ocean, notably within the $\mathrm{AZ}$ 682 and SZ. In the North Pacific, Hg levels in both predators and prey have been found to increase 
683

684

685

686

687

688

689

690

691

692

693

694

695

696

697

698

699

700

701

702

703

704

705

706

707

708

709

710

711

with depth, as does the concentration of methylated Hg in seawater (Choy et al., 2009). This association between $\mathrm{Hg}$ levels in organisms and in their ambient environment, together with our observations of highly elevated $\mathrm{MeHg}_{\mathrm{T}}$ concentrations in Antarctic waters, suggest that Antarctic marine biota are exposed to high levels of $\mathrm{MeHg}_{\mathrm{T}}$, deriving from both natural and anthropogenic sources of atmospheric-borne inorganic $\mathrm{Hg}$ methylated in situ, and oceanic preformed methylated species, advected with CDW. As fishing activities exte to more remote regions, including Antarctica, the presence of high $\mathrm{MeHg}_{\mathrm{T}}$ concentrations in Antarctic waters may have important implications for the health of human consumers.

\section{ACKNOW LEDGEMENTS}

Thanks are due to Mark Rosenberg and Alicia Navidad, Mark Rayner, Carrie Bloomfield and Laura Herraiz Borreguero for hydrochemistry analyses and data quality control. This research has been supported by the Australian Antarctic Science projects 2793 and 2900, the Australian Antarctic Division, the Australian Government (ACE CRC) and IFREMER International Division. This work contributes to the Australian Climate Change Science Program and the ternational Polar Year (CASO and GEOTRACES). We thank the captain and crew of R/SV "Aurora Australis". Thanks are also due to NIWA for use of the non-contaminating rosette and Niskin bottles.

\section{REFERENCES}

Ariya P. A., Khalizov A. and Gidas A. (2002) Reaction of gaseous mercury with atomic and molecular halogens/ Kinetics, product studies, and atmospheric implica I. J. Phys. Chem. A 106, 73107320.

Bargagli R., Agnorelli C., Borghini F. and Monaci F. ( ) Enhanced Deposition and Bioaccumulation of Mercury in Antarctic Terrestrial Ecosystems Facing Coastal Polynya. Environ. Sci. Technol. 39, 8150-8155.

Bargagli R. (2008) Environmental contamination in Antarctic ecosystems. Sci. Total Environ. 400, 212226.

Black F. J., Conaway C. H. and Flegal A. R. (2009) Stability of Dimethyl Mercury in Seawater and Its Conversion to Monomethyl Mercury. Environ. Sci. Technol. 43, 4056-4062, 10.1021/es9001218. 
Bowie A. R., Lannuzel D., Remenyi T. A., Wagener T., Lam P. J., Boyd P. W., Guieu C., Townsend A. T. and Trull T. W. (2009) Biogeochemical iron budgets of the Southern Ocean south of Australia: Decoupling of iron and nutrient cycles in the subantarctic zone by the summertime supply. Global Biogeochem. Cycles 23, 1-14 GB4034, doi:10.1029/2009GB003500.

Brooks S., Lindberg S., Southworth G., and Arimoto R. (2008) Springtime atmospheric mercury speciation in the McMurdo, Antarctica coastal region. Atmos. Environ. 42, 2885-2893.

Bruland K. W. and Lohan M. C. (2003) Control of Trace Metal in Seawater. Chap. 6.02. p:23-47. In: Treatise on Geochemistry, Vol. 6 (The Oceans and Marine Geochemistry). Holland, H. D. and. Turekian K. K. Elsevier.

Chaulk A., Stern G. A., Armstrong D., Barber D. G., and Wang F. (2011) Mercury Distribution and Transport Across the Ocean-Sea-Ice-Atmosphere Interface in the Arctic Ocean. Environ. Sci. Technol. Dx.doi.org/10.1021/es103434c.

Choy C. A., Popp B. N., Kaneko J. J. and Drazen J. C. (2009) The influence of depth on mercury levels in pelagic fishes and their prey. PNAS 106, 13865-13869.

Cossa D., Martin J.-M., Takayanagi K. and Sanjuan J. (1997) The distribution and cycling of mercury species in the western Mediterranean. Deep Sea Res. II 44, 721-740.

Cossa D., Cotte-Krief M. H., Mason R. P. and Bretaudeau-Sanjuan J. (2004) Total mercury in the water column near the shelf edge of the European continental margin. Mar. Chem. 90, 21-29.

Cossa D. and Coquery M. (2005) The Mediterranean Mercury Anomaly, a Geochemical or a ogical Issue. p. 177-208. In: The Mediterranean Sea, A. Saliot editor. The Handbook of Environmental Chemistry, Vol. 5, Water Pollution, Part K. Springer-Verlag, Berlin-Heidelberg. 413pp.

Cowley R. (1999) Hydrochemistry operations manual. CSIRO Marine Laboratories Report 236. CSIRO Marine Research, Melbourne.

Dommergue A., Sproveri F., Pirrone, N., Ebinghaus R., Brooks S., Courteaud J. and Ferrari C. (2010) Overview of mercury measurements in the Antarctic trop here. Atmos. Chem. Phys., 10, 33093319.

Ebinghaus R., Kock H. H., Temme Ch., Einax J. W., Löwe A. G., Richter A., Burrows J. P. and Schroeder W. H. (2002) Antarctic Springtime Depletion of Atmospheric Mercury. Environ. Sci. Technol. 36, 1238-1244. 
Eicken H. (1992) Salinity profiles of Antarctic sea ice: field data and model results. J. Geophys Res. 97 (C10), 15545-15557.

Fitzgerald W. F. and Lamborg C. H. (2003) Geochemistry of Mercury in the Environment. $\underline{\text { In: Treatise of }}$ Geochemistry, Turekian K. K. editor. Vol. 9. p. 107-148. Elsevier.

Fitzgerald W. F., Lamborg C. H. and Hammerschmidt C. R. (2007) M ine biogeochemical cycling of mercury. Chem. Rev. 107, 641-662, 10.1021/cr050353m.

Garfeldt K., Munthe J., Strömberg D. and Lindqvist O. (2003) A kinetic study on the abiotic methylation of divalent mercury in aqueous phase. Sci. Total Environ. 304, 127-136.

751 Grasshoff, K. (1976) Methods of seawater analysis. Verlag Chemie, Weinheim. Basins. Environ. Sci. Technol. 33, 4194-4198.

Heimbürger L.-E., Cossa D., Marty J.-C., Migon C., Averty B., Dufour A. and Ras J. (2010) Methyl mercury distributions in relation to the presence of $n$ and picophytoplankton in an oceanic water column (Ligurian Sea, North-western Mediterranean). Geochim. Cosmochim. Acta, 74, 5549-4459.

Hindell M. A., Brothers N. and Gales R. (1999) Mercury and cadmium concentrations in the tissues of three species of southern albatrosses. Polar Biol. 22, 102-108.

Horvat M., Kotnik J., Logar M., Fajon V., Zvonaric T. and Pirrone N. (2003) Speciation mercury in surface and deep-sea waters in the Mediterranean Sea. Atmos. Environ. 37, 93-108.

Knapp, G. P., Stalcup M. and Stanley R. J. (1990) Automated oxygen titration and salinity determination. Woods Hole Oceanographic Institute Technical Report WHOI-90-35.

Lamborg C. H., Tseng C. M., Fitzgerald W. F., Balcom P. H. and Hammerschmidt C. R. (2003)

Kotnik O., Horvat M., Tessier E., Ogrinc N., Monperrus M., Amouroux D., Fajon V., Gibicar D., Žižek S., Sprovieri F. and Pirrone N. (2007) Mercury speciation in surface and deep waters of the Mediterranean Sea. Mar. Chem., 107, 13- 30. Determination of the Mercury Complexation Characteristics of Dissolved Organic Matter in Natural Waters with "Reducible Hg" Titrations. Environ. Sci. Technol. 37, 3316-3322.

Lannuzel D., de Jong J. T. M., Schoemann V., Trevena A., Tison J.-L. and Chou L. (2006) Development of a sampling and flow injection analysis technique for iron determination in the sea ice environment. Anal. Chim. Acta 556, 476-483.

Lannuzel D., Schoemann V., de Jong, J. T. M., Chou L., Delille B., Becquevort S. and Tison J.-L. (2008) Iron study during a time series in the western Weddell pack ice. Mar. Chem. 108, 85-95. 
Lannuzel D., Schoemann V., Pasquer B., van der Merwe P. and Bowie A. (2010) Distribution of dissolved iron in Antarctic sea ice: spatial, seasonal and inter-annual variability. J. Geophys. Res. Biogeo. 115, G03022, doi:10.1029/2009JG001031.

Lannuzel D., Bowie A. R., van der Merwe P., Townsend A d Schoemann V. (2011) Distribution of dissolved and particulate metals in Antarctic sea ice. Mar. Chem. DOI : 10.1016/j.marchem. 2011.01.004.

Larose C., Dommergue A., De Angelis M., Cossa D., Averty B., Marusczak N., Soumis N., Schneider D. and Ferrari C. (2010) Springtime changes in snow chemi lead to new insights into mercury methylation in the Arctic. Geochim. Cosmochim. Acta 74, 6263-6275.

Laurier F. J. G., Mason R. P., Gill G. A. and Whalin L (2004) Mercury distributions in the North Pacific Ocean - 20 years observations. Mar. Chem. 90, 3-19.

Lindberg S. E., Brooks S., Lin C.-J., Scott K., Meyers T., Chambers L., Landis M. and Stevens R. (2001) Formation of reactive gaseous mercury in the Arctic: evidence of oxidation of $\mathrm{Hg}^{0}$ to gas phase $\mathrm{Hg}^{\mathrm{II}}$ compounds after Arctic sunrise. Water Air Soil Pollut. Focus 1, 295-302.

Lindberg S. E., Brooks, S., Lin C.-J., Scott K. J., Landis M. S. D., Stevens, R. K., Goodsite M. and Richter A. (2002) Dynamic oxidation of gaseous mercury in the Arctic troposphere at polar sunrise. Environ. Sci. Technol. 36, 1245-1256.

Malcolm E. C., Tuit C. B., Jayakumar A. D. and Morel F. M. M. (2004) Investigation o mercury methylation by bacteria in the open ocean. In $7^{\text {th }}$ Intern. Conf. On Mercury as a Global pollutant. RMZ-Materails and Geoenvironment 51, 1193-1194 (Abstract).

Mason R. P. and Fitzgerald W. F. (1990) Alkylmercury species in the Equatorial Pacific. Nature 347, 457459.

Mason, R. P. and Fitzgerald W. F. (1993) The distribution and biogeochemical cycling of mercury in the Equatorial Pacific-Ocean. Deep Sea Res. I 40, 1897-1924.

Mason R. P., Rolfhus K. R. and Fitzgerald W. F. (1998) Mercury in the North Atlantic. Mar. Chem. 61, $37-53$.

Mason R. P., Lawson N.M. and Sheu G.-R. (2001) Mercury in the Atlantic Ocean: Factors contr $\quad \mathrm{g}$ airsea exchange of mercury and its distribution in the upper waters. Deep-Sea Res. II 48, 2829-2853. equatorial Atlantic. Deep-Sea Res. II 46, 937-956. 
Mason R. P. and Gill G. A. (2005) Mercury in the Marine Environment. Chap 10. In: Mercury Sources, Measurements, Cycles, and Effects. Parsons M. B. and P ival J. B. editors. Mineralogical Association of Canada. Short Course, Series Volume 34, Halifax, Nova Scotia, Canada, p. 179-216.

Nakawo M. and Sinha N. K. (1981) Growth rate and salinity profile of first-year sea ice in the Arctic. $J$. Glaciol. 27, 315-330.

Orsi A. H., Whitworth T. and Nolin W. D. (1995) On the meridional extent and fronts of the Antarctic Circumpolar Current. Deep Sea Res. I 42, 641-673.

Orsi A. H., Smethie W. M. and Bullister J. B. (2002) On the total input of Antarctic waters to the deep ocean: A preliminary estimate from chlorofluorocarbon measurements. Journal of Geophysical Research 107(C8):3122.

Parker J. L. and Bloom N. S. (2005) Preservation and storage techniques for low-level aqueous mercury speciation. Sci. Total Environ. 337, 253-263. compounds in surface waters of polar and other remote eans by GC-AFD. Intern. J. Environ. Anal. Chem. 71, 41-56. bacteria as a significant natural source for atmospher heavy metals in polar regions. Chemosphere 39, 89-102.

Poulain A. J., Lalonde J. D., Amyot M., Shead J. A., Raaofie F. and Ariya P.A. (2004) Redox transformations of mercury in an Arctic snowpack at springtime. Atmos. Environ. 38, 6763-6774.

Rintoul S. R. (2006) Circumpolar Deep Water. pp. 240-242, In: Encyclopedia of the Antarctic, Routledge, New York,

Rintoul S. R. and Bullister J. (1999) A late winter hydrographic section between Tasmania and Antarctica. Deep Sea Res. I 46, 1417-1454. springtime depletion of mercury. Nature 394, 331-332.

830 Sedwick P. N., Edwards P. R., Mackey D. J., Grif? ths F. B., Parslow J. S. (1997) Iron and manganese in surface waters of the Australian subantarctic region. Deep Sea Res. I, 44, 1239-1253. regional trends of atmospheric mercury concentrations. Geophys. Res. Lett. 22, 2143-2146. 
Soerensen, A. L., Skov H., Jacob D. J., Soerensen B. T and Johnson M. S. (2010) Global Concentrations of Gaseous Elemental Mercury and Reactive Gaseous Mercury in the Marine Boundary Layer. Environ. Sci. Technol. 44, 7425-7430.

Sokolov S. (2008) Chlorophyll blooms in the Antarctic Zone south of Australia and New Zealand in reference to the Antarctic Circumpolar Current fronts and sea ice forcing. J. Geophys. Res. Oceans 113, C3, Article Number C03022.

Sokolov S. and Rintoul S. R. (2002) The structure of S hern Ocean fronts at 140E. J. Mar. Syst. 37, $151-184.54$.

Sokolov S. and Rintoul S. R. (2007) Multiple jets of the Antarctic Circumpolar Current south of Australia. J. of Phys. Oceanogr. 37, 1394-1412.

Sproveri F., Pirrone N. and Hedgecock I. M. (2002) Intensive atmospheric measurements at Terra Nova Bay in Antarctica during November and December 2000. J. Geophys. Res. 107 (D23), 4722-4729.

Stoichev T., Martin-Doimeadios, R. C. R., Tessier, E., Amouroux, D., and Donard, O. F. X. (2004) Improvement of analytical performances for mercury speciation by on-line derivatization, cryofocussing and atomic fluorescence spectrometry. Talanta 62, 433-438.

Sullivan C. W., Arrigo K. R., Mcclain C. R., Comiso J. C. and Firestone J. (1993) Distributions of phytoplankton blooms in the Southern Ocean. Science 262, 1832-1837.

Sunderland E. M., Krabbenhoft D. P., Moreau J. W., Strode S. A. and Landing W. M. (2009) Mercury sources, distribution, and bioavailability in the North Pacific Ocean: Insights from data and models. Global Biogeo. Cycles 23, 14, Gb201010.1029/2008gb003425.

Sunderland E. M. and Mason R. P. (2007) Human impacts on open ocean mercury concentrations. Global Biogeo. Cycles 21, 1-15. doi:10.1029/2006GB002876.

Temme C., Einax J. W., Ebinghaus R. and Schroeder W. H 003) Measurements of Atmospheric Mercury Species at a Coastal Site in the Antarctic and Over the South Atlantic Ocean During Polar Summer. Environ. Sci. Technol. 37, 22-31.

van der Merwe P., Lannuzel D., Bowie A. R. and Meiners K. M. (2011) High temporal resolution observations of spring fast-ice melt and seawater iron enrichment in East Antarctica. J. Geophys. Res. Biogeo., in press.

Weeks W. F. and Ackley S. F. (1986) The growth, structure and properties of sea ice. pp. 9-164. In: The Geophysics of sea ice, Untersteiner N. editor. NATO ASI series. 
866 Table 1. Summary statistics for $\mathrm{Hg}_{\mathrm{T}}, \mathrm{Hg}_{\mathrm{R}}$ and $\mathrm{MeHg}_{\mathrm{T}}$ concentrations in various water masses of the

867 SO. CDW: Circumpolar Deep W ater (salinity >34.6, depth 500-3000m); AAIW: Antarctic

868 Intermediate Water (34.10-34.60; 2-5 $\left.{ }^{\circ} \mathrm{C}\right)$; AABW: Antarctic Bottom Water (34.65-34.75 and

$\left.869<1^{\circ} \mathrm{C}\right)$. Mean \pm standard deviation, minimum and maximum in brackets and number of samples

870 in italics.

\begin{tabular}{lcccc}
\hline & $\mathrm{Hg}_{\mathrm{T}}$ & $\mathrm{Hg}_{\mathrm{R}}$ & $\mathrm{MeHg}_{\mathrm{T}}$ & DGHg \\
\hline CDW & $1.19 \pm 0.27$ & $0.39 \pm 0.08$ & $0.48 \pm 0.18$ & $0.22 \pm 0.07$ \\
& $(0.95-1.80) 11$ & $(0.21-0.55) 25$ & $(0.09-0.77) 30$ & $(0.10-0.31) 13$ \\
\hline AAIW & $1.15 \pm 0.22$ & $0.38 \pm 0.11$ & $0.44 \pm 0.17$ & $0.24 \pm 0.03$ \\
& $(0.82-1.56) 10$ & $(0.14-0.64) 24$ & $(0.04-0.86) 31$ & $(0.21-0.29) 8$ \\
\hline AABW & $1.35 \pm 0.39$ & $0.48 \pm 0.23$ & $0.52 \pm 0.11$ & $0.24 \pm 0.04$ \\
& $(0.98-1.99) 14$ & $(0.28-1.31) 16$ & $(0.15-0.68) 19$ & $(0.20-0.30) 6$ \\
\hline
\end{tabular}

873 Table 2. T-test. Probabilities for the significance of the differ $\mathrm{s}$ in mean concentration

874 between various water masses. (*) Significant differen at $85 \%$ confidence; $(* *)$ Significant

875 differences at $95 \%$ confidence level.

\begin{tabular}{lcccc}
\hline & $\mathrm{Hg}_{\mathrm{T}}$ & $\mathrm{Hg}_{\mathrm{R}}$ & $\mathrm{MeHg}_{\mathrm{T}}$ & $\mathrm{DGHg}$ \\
\hline AABW $v$ s AAIW & $0.1277 *$ & $0.1205^{*}$ & $0.0397 * *$ & 0.8543 \\
\hline AABW vs CDW & 0.2170 & $0.1372 *$ & 0.3088 & 0.6047 \\
\hline AAIW vs CDW & 0.7772 & 0.7954 & 0.3393 & 0.4456 \\
\hline
\end{tabular}


Figure 1: Sampling stations along the SR3 CASO-GEOTRACES transect 879 in the Southern Ocean.

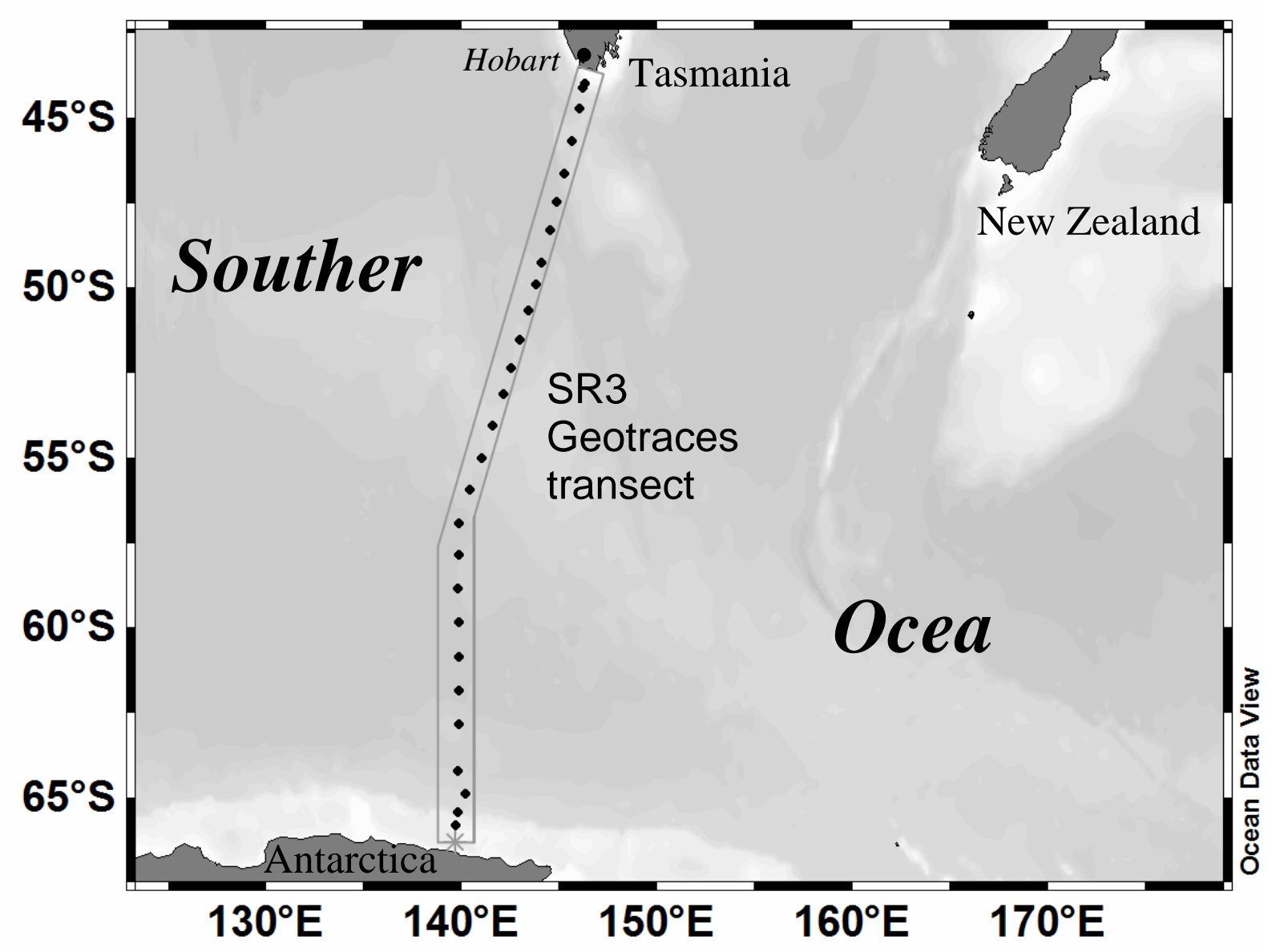


Figure 2 : Distributions of (a) potential temperature (Tpot-0), (b) salinity, (c) phosphate (PO4) and (d) dissolved oxygen along the of the SR3 CASO-GEOTRACES transect in the Southern Ocean.
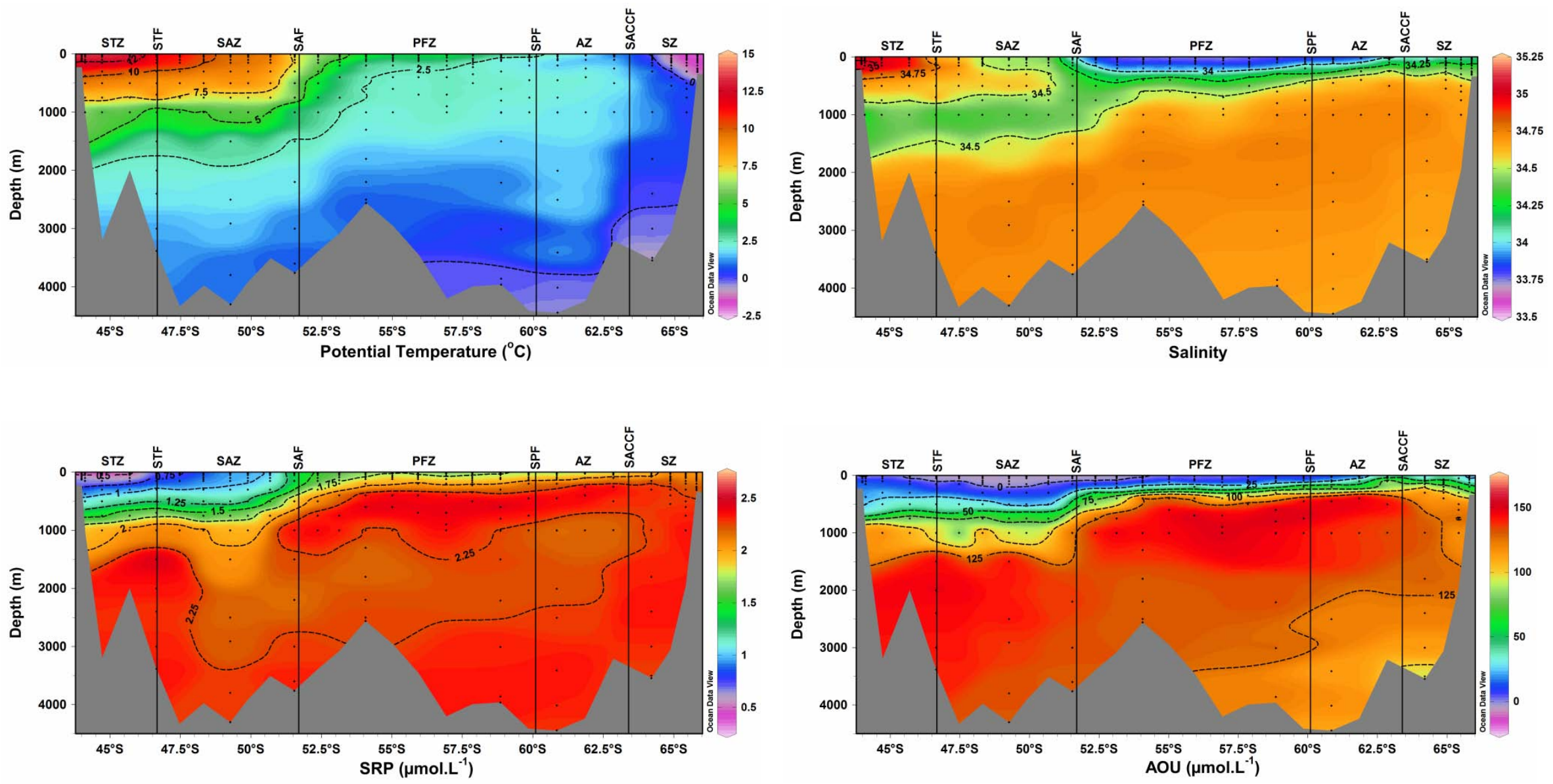
Figure 3 : Total mercury $(\mathrm{HgT})$ distribution along the SR3 CASO-GEOTRACES transect in the Southern Ocean.

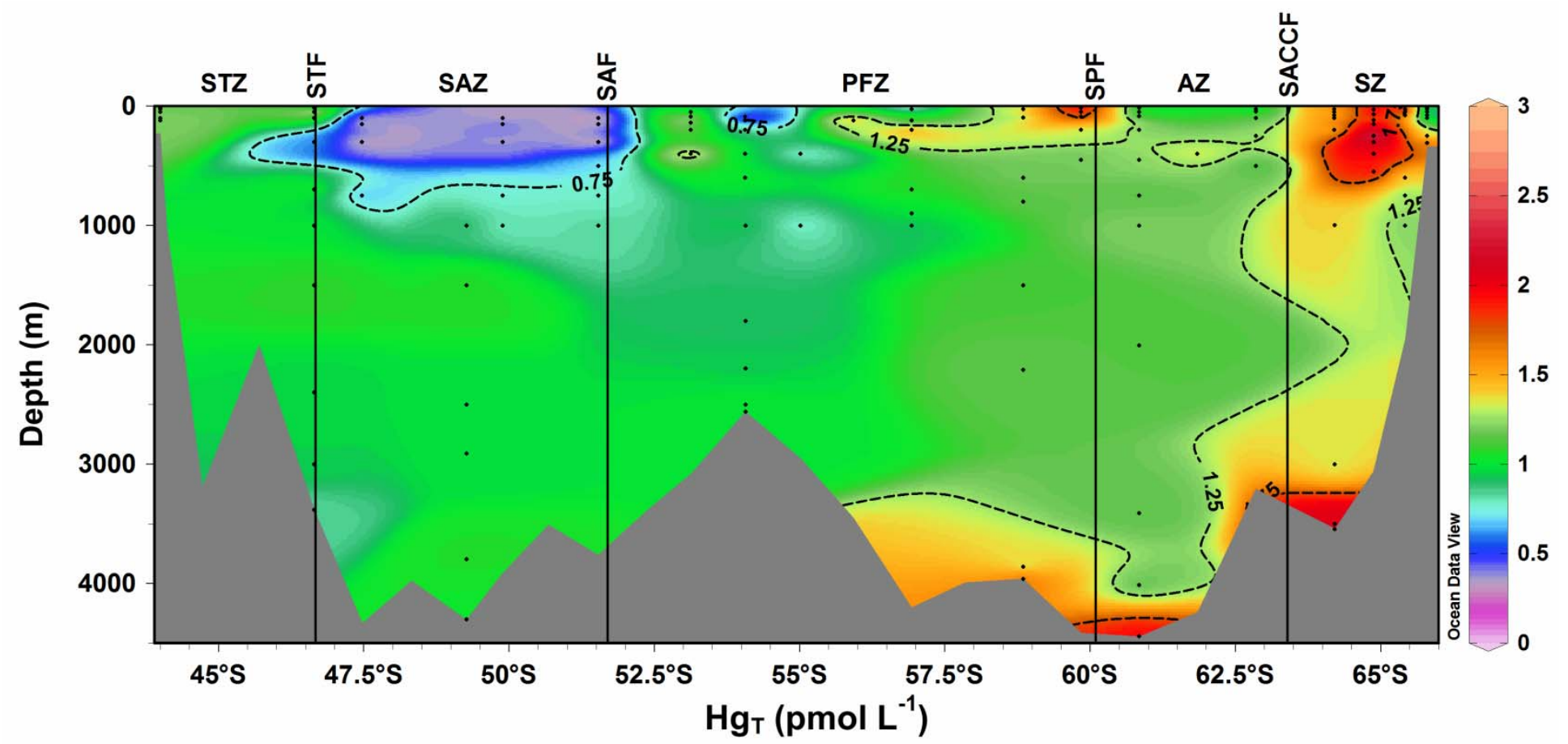


Figure 4 : Total mercury (HgR) distribution along the SR3 CASO-GEOTRACES transect in the Southern Ocean.

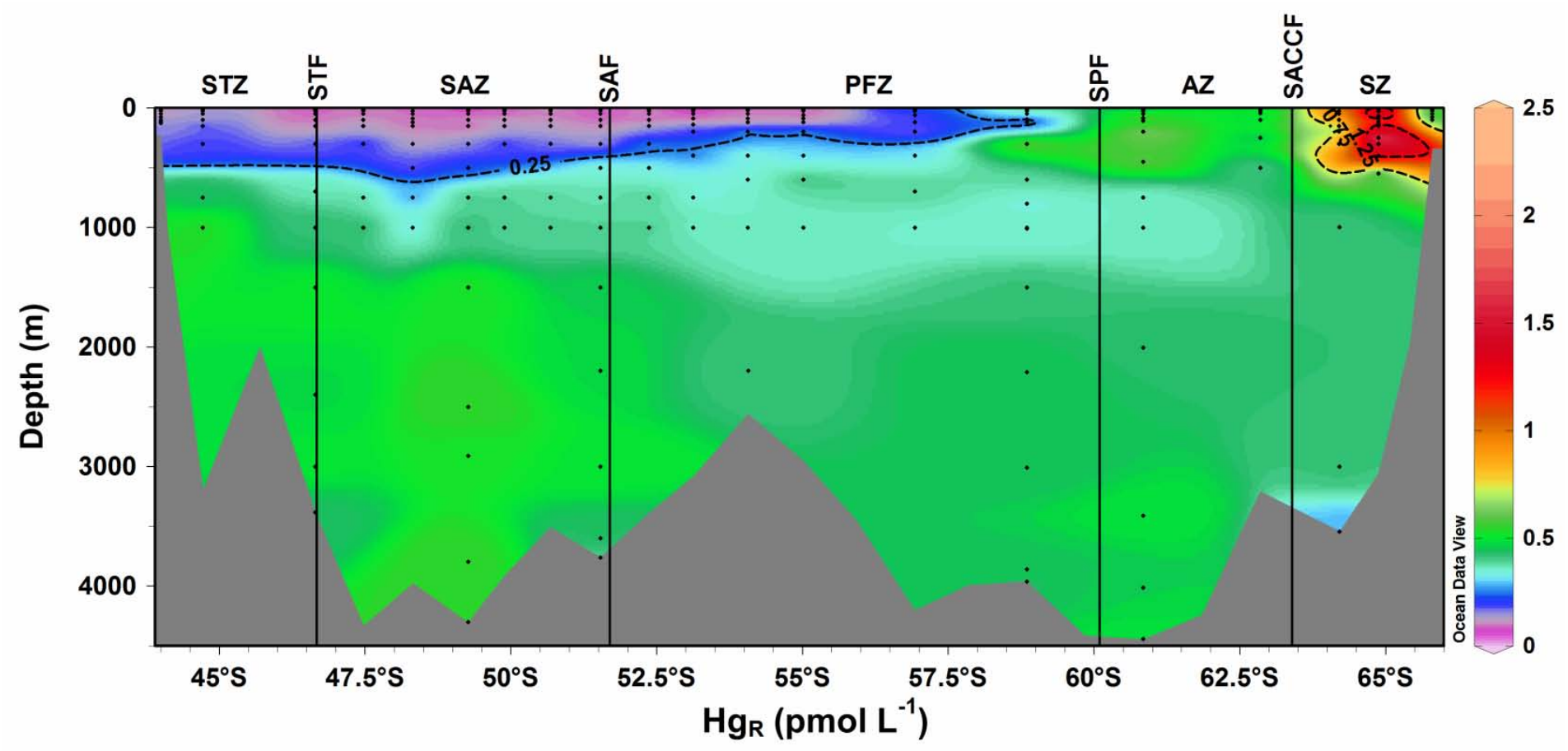


Figure 6 : Methylated mercury species (MeHgT) distribution along the SR3 CASO-GEOTRACES transect in the Southern Ocean.

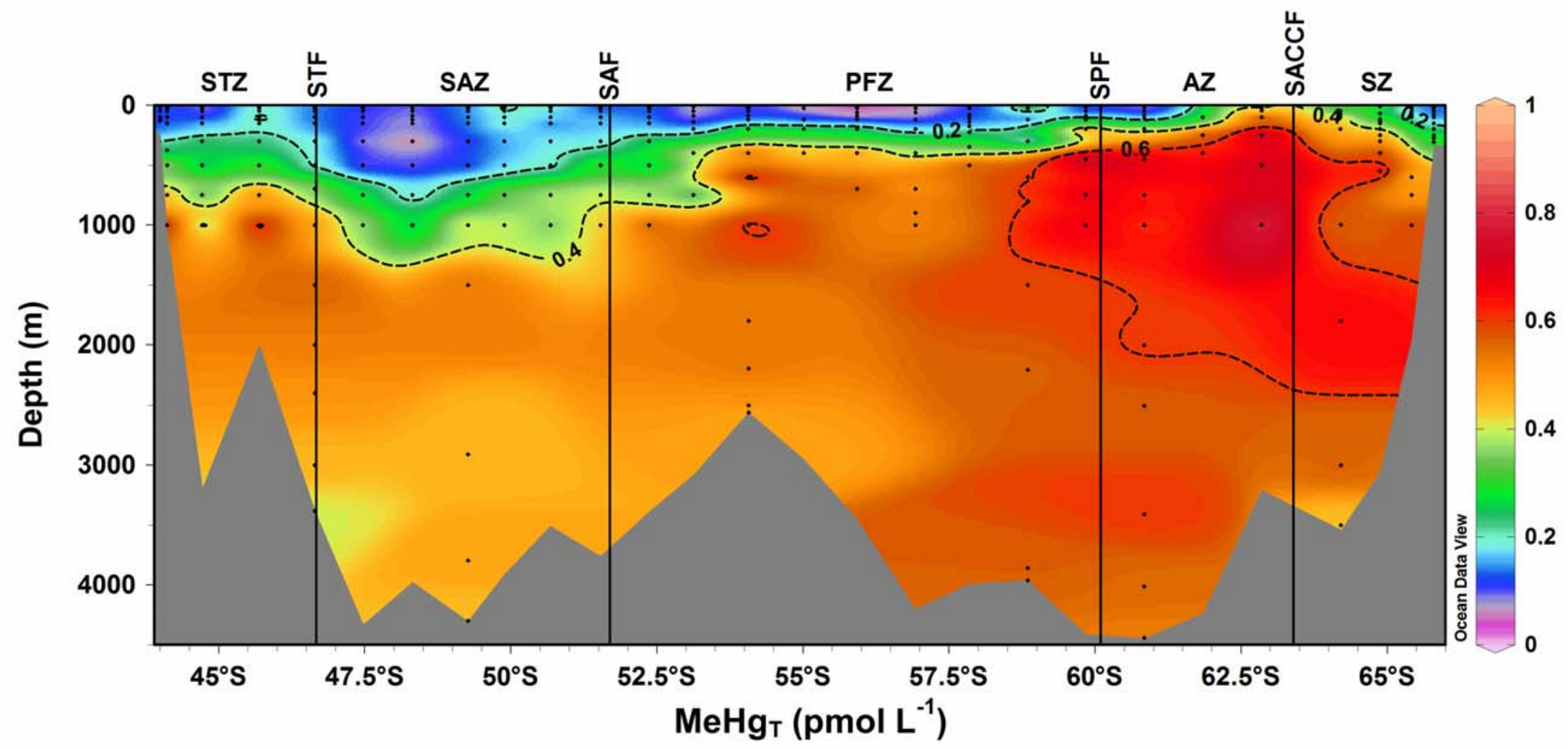


Figure 7 : Vertical distribution of dissolved gaseous mercury (DGHg) along the SR3 CASO GEOTRACES transect in the Southern Ocean.

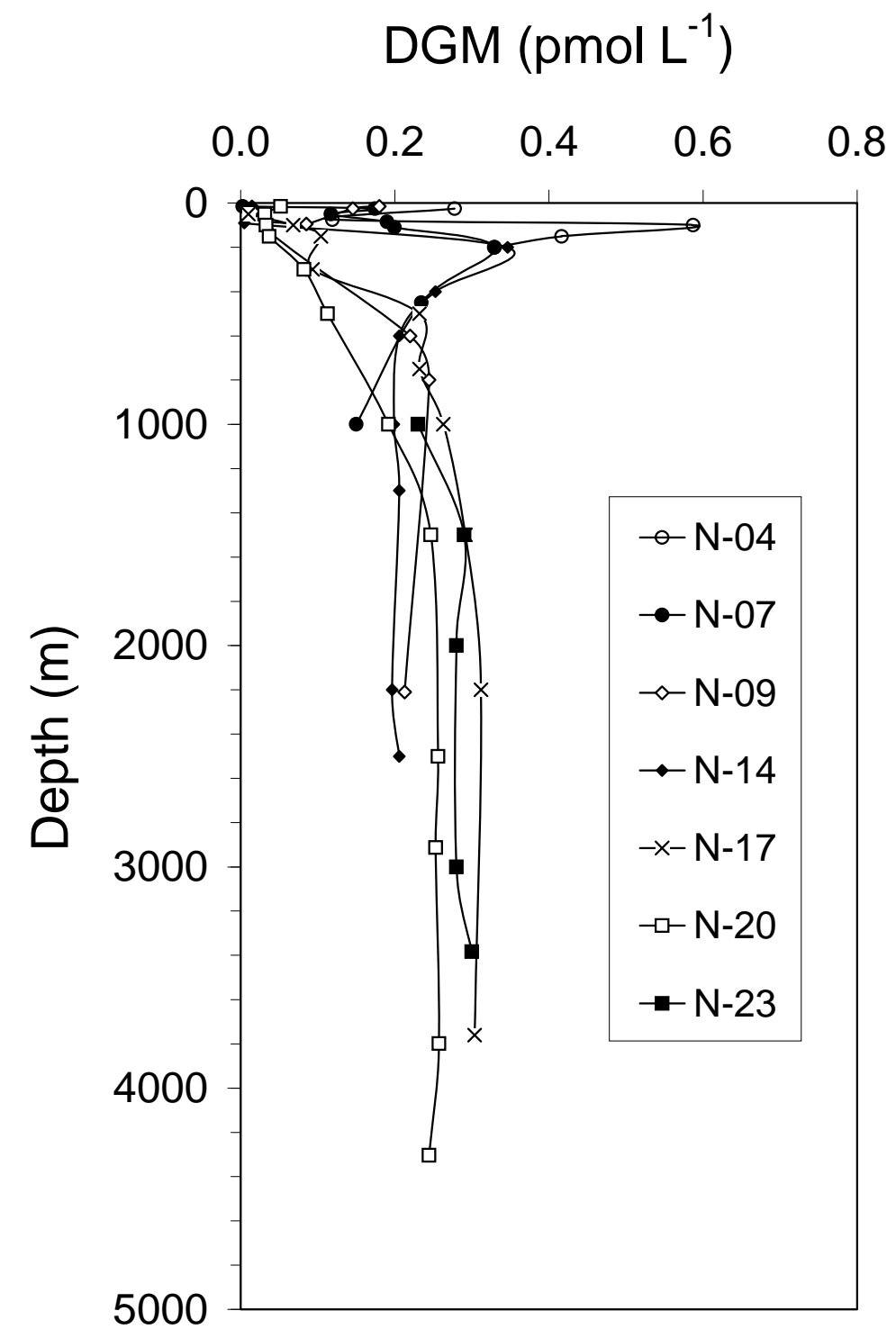


Figure 8 : Vertical distributions of $\mathrm{Hg}$ species in snow, bulk sea ice and seawater in the coastal sea ice environment $12 \mathrm{~km}$ northeast of the Casey Station (Australian East Antarctic sector) (66 $\left.16^{\circ} \mathrm{S} ; 1^{\circ} 0^{\circ} 39^{\prime} \mathrm{E}\right)$. Figures "a" to "e" referee to the snow and sea ice continuum, figures "f" to "j"referee to seawater.
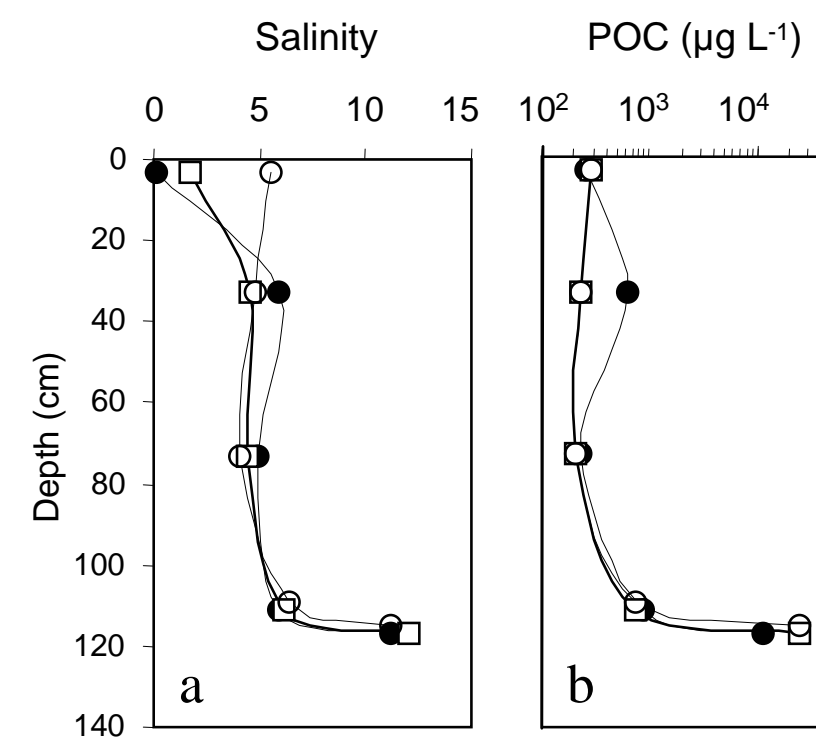

\section{Chla $\left(\mu \mathrm{g} \mathrm{L}^{-1}\right)$}

$0.01 \quad 1 \quad 100$

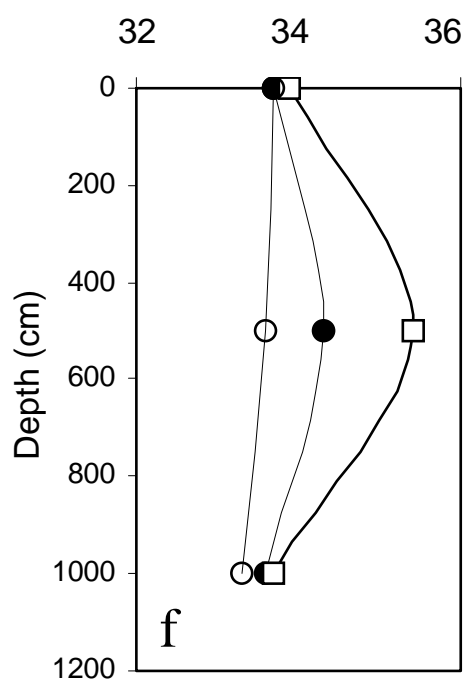

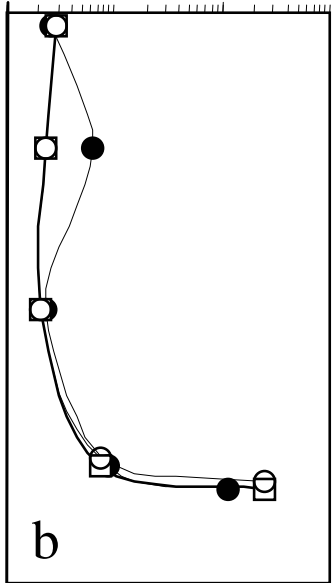
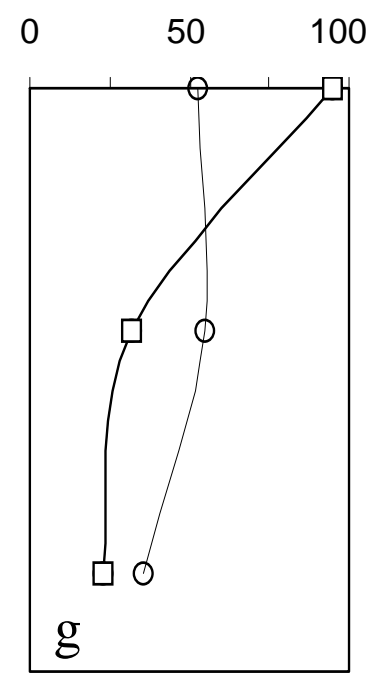

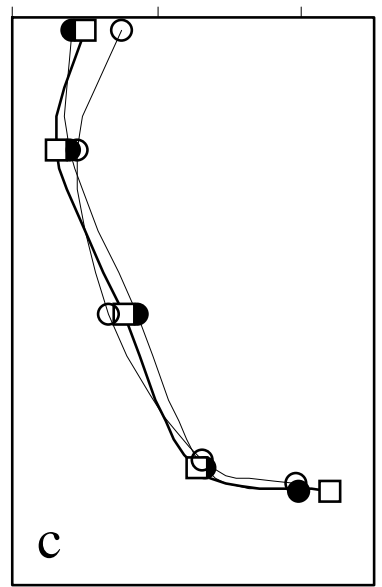

$\mathrm{Hg}_{\mathrm{T}}(\mathrm{pmol} \mathrm{L-1})$

$\mathrm{MeHg}_{\mathrm{T}}(\mathrm{pmol} \mathrm{L-1})$

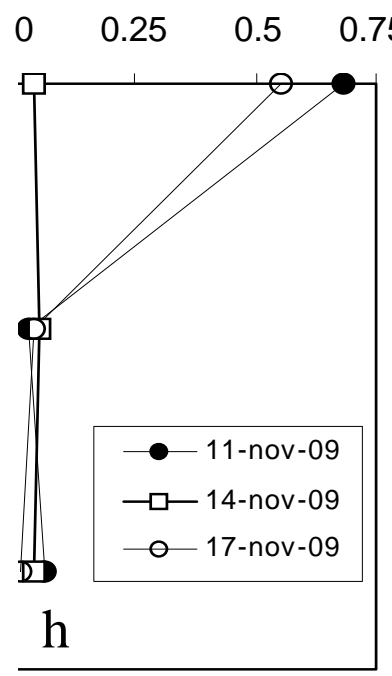

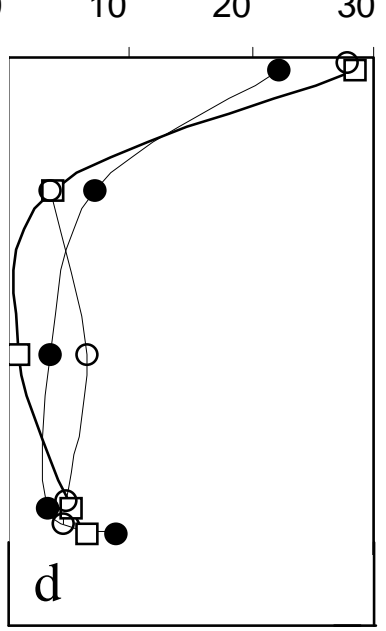
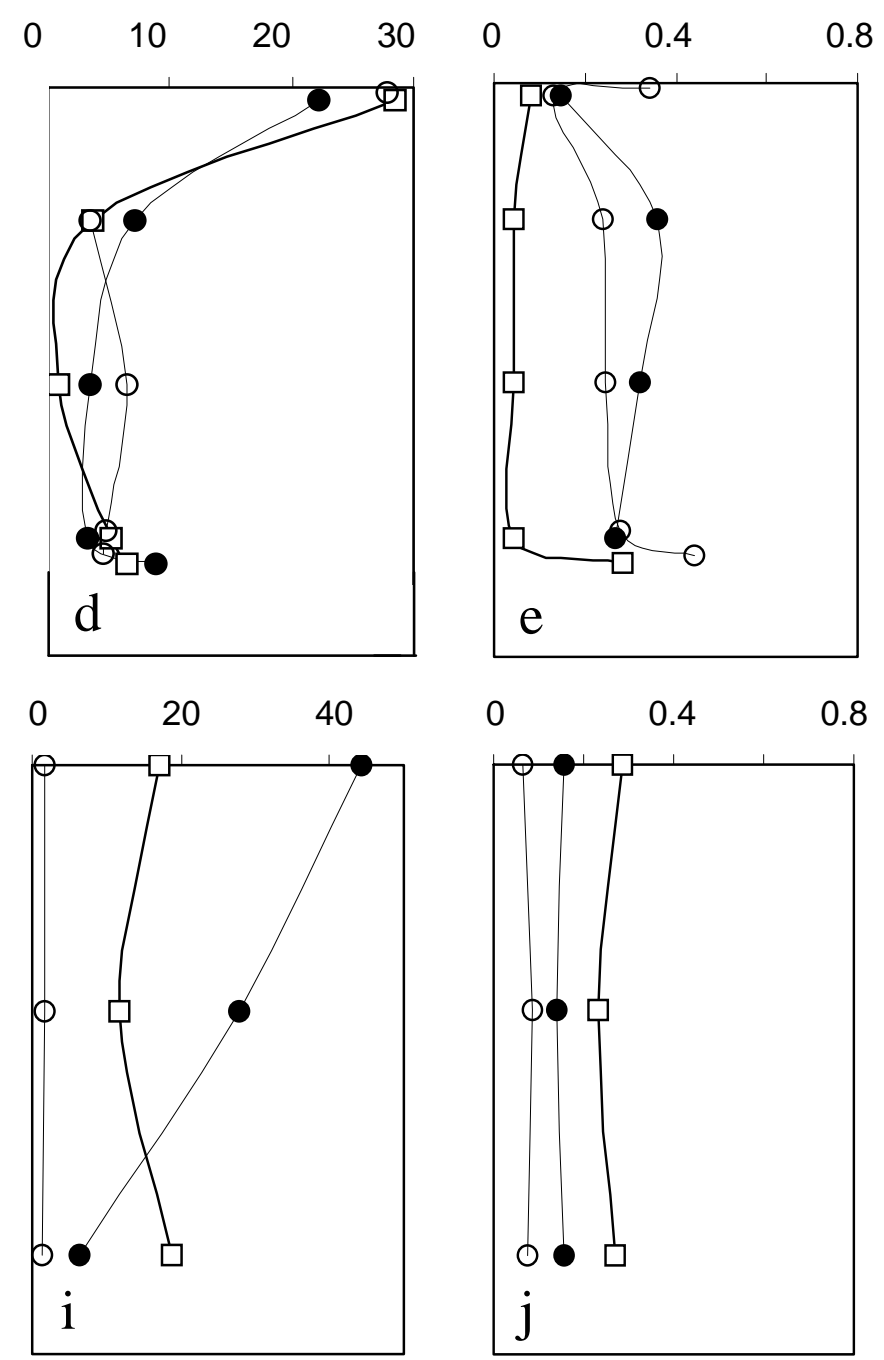
898 Electronic annex 1. Sampling dates and positions along the SR3 CASO-GEOTRACES transect in the 899 Southern Ocean from Adelie Land (Antarctic continent) and Tasmania (Australia). Stations with ice-pack 900 cover are indicated in italics.

901

\begin{tabular}{|c|c|c|c|}
\hline Station & Date $(\mathrm{dd} / \mathrm{mm} / \mathrm{yy})$ & Position (Lat., Long.) & Sea bottom depth (m) \\
\hline$N-01$ & $28 / 03 / 2008$ & $65^{\circ} 48.19^{\prime} S, 139^{\circ} 40.81^{\prime} E$ & 338 \\
\hline$N-02$ & $29 / 03 / 2008$ & $65^{\circ} 25.58^{\prime} S, 139^{\circ} 50.61^{\prime} E$ & 1000 \\
\hline$N-03$ & $30 / 03 / 2008$ & $64^{\circ} 52.71^{\prime} \mathrm{S}, 140^{\circ} 12.63^{\prime} \mathrm{E}$ & 3061 \\
\hline $\mathrm{N}-04$ & $31 / 03 / 2008$ & $64^{\circ} 12.45^{\prime} \mathrm{S}, 139^{\circ} 50.47^{\prime} \mathrm{E}$ & 3547 \\
\hline $\mathrm{N}-05$ & $31 / 03 / 2008$ & $62^{\circ} 51.28^{\prime} \mathrm{S}, 139^{\circ} 51.48^{\prime} \mathrm{E}$ & 3210 \\
\hline $\mathrm{N}-06$ & $01 / 04 / 2008$ & $61^{\circ} 50.99^{\prime} \mathrm{S}, 139^{\circ} 50.88^{\prime} \mathrm{E}$ & 4240 \\
\hline $\mathrm{N}-07$ & $02 / 04 / 2008$ & $60^{\circ} 51.02^{\prime} \mathrm{S}, 139^{\circ} 51.13^{\prime} \mathrm{E}$ & 4243 \\
\hline $\mathrm{N}-08$ & 02/04/2008 & $59^{\circ} 50.93^{\prime} \mathrm{S}, 139^{\circ} 51.57^{\prime} \mathrm{E}$ & 4415 \\
\hline $\mathrm{N}-09$ & 03/04/2008 & $58^{\circ} 51.04^{\prime} \mathrm{S}, 139^{\circ} 50.31^{\prime} \mathrm{E}$ & 3962 \\
\hline $\mathrm{N}-10$ & 04/04/2008 & $57^{\circ} 51.01^{\prime} \mathrm{S}, 139^{\circ} 51.10^{\prime} \mathrm{E}$ & 3993 \\
\hline $\mathrm{N}-11$ & 04/04/2008 & $56^{\circ} 55.77^{\prime} \mathrm{S}, 139^{\circ} 51.04^{\prime} \mathrm{E}$ & 4200 \\
\hline $\mathrm{N}-12$ & 05/04/2008 & $55^{\circ} 55.76^{\prime} \mathrm{S}, 140^{\circ} 24.56^{\prime} \mathrm{E}$ & 3450 \\
\hline $\mathrm{N}-13$ & 06/04/2008 & $55^{\circ} 01.21^{\prime} \mathrm{S}, 14101.12^{\prime} \mathrm{E}$ & 2953 \\
\hline $\mathrm{N}-14$ & 06/04/2008 & $54^{\circ} 04.18^{\prime} \mathrm{S}, 141^{\circ} 36.14^{\prime} \mathrm{E}$ & 2560 \\
\hline $\mathrm{N}-15$ & $07 / 04 / 2008$ & $53^{\circ} 07.90^{\prime} \mathrm{S}, 142^{\circ} 08.30^{\prime} \mathrm{E}$ & 3077 \\
\hline $\mathrm{N}-16$ & 08/04/2008 & $52^{\circ} 22.17^{\prime} \mathrm{S}, 142^{\circ} 32.05^{\prime} \mathrm{E}$ & 3391 \\
\hline $\mathrm{N}-17$ & $10 / 04 / 2008$ & $51^{\circ} 32.37^{\prime} \mathrm{S}, 142^{\circ} 59.73^{\prime} \mathrm{E}$ & 3761 \\
\hline $\mathrm{N}-18$ & $10 / 04 / 2008$ & $50^{\circ} 40.89^{\prime} \mathrm{S}, 143^{\circ} 25.16^{\prime} \mathrm{E}$ & 3506 \\
\hline $\mathrm{N}-19$ & $11 / 04 / 2008$ & $49^{\circ} 53.49^{\prime} \mathrm{S}, 143^{\circ} 48.03^{\prime} \mathrm{E}$ & 3914 \\
\hline $\mathrm{N}-20$ & $12 / 04 / 2008$ & $49^{\circ} 16.20^{\prime} \mathrm{S}, 144^{\circ} 05.96^{\prime} \mathrm{E}$ & 4216 \\
\hline $\mathrm{N}-21$ & $12 / 04 / 2008$ & $48^{\circ} 19.19^{\prime} \mathrm{S}, 144^{\circ} 31.81^{\prime} \mathrm{E}$ & 3975 \\
\hline $\mathrm{N}-22$ & $13 / 04 / 2008$ & $47^{\circ} 28.32^{\prime} \mathrm{S}, 144^{\circ} 54.07^{\prime} \mathrm{E}$ & 4330 \\
\hline $\mathrm{N}-23$ & $13 / 04 / 2008$ & $46^{\circ} 39.00^{\prime} \mathrm{S}, 145^{\circ} 14.91^{\prime} \mathrm{E}$ & 3383 \\
\hline $\mathrm{N}-24$ & $14 / 04 / 2008$ & $45^{\circ} 41.99^{\prime} \mathrm{S}, 145^{\circ} 39.45^{\prime} \mathrm{E}$ & 2000 \\
\hline $\mathrm{N}-25$ & $14 / 04 / 2008$ & $44^{\circ} 43.20^{\prime} \mathrm{S}, 146^{\circ} 03.06^{\prime} \mathrm{E}$ & 3193 \\
\hline $\mathrm{N}-26$ & $15 / 04 / 2008$ & $44^{\circ} 07.09^{\prime} \mathrm{S}, 146^{\circ} 13.37^{\prime} \mathrm{E}$ & 1040 \\
\hline $\mathrm{N}-27$ & $15 / 04 / 2008$ & $43^{\circ} 59.92^{\prime} \mathrm{S}, 146^{\circ} 19.31^{\prime} \mathrm{E}$ & 227 \\
\hline
\end{tabular}


904 Electronic annex 2. Mercury species distribution in the coastal sea ice environment $12 \mathrm{~km}$ northeast of the Casey Station (Australian

905 East Antarctic sector) (66 $\left.16^{\circ} \mathrm{S} ; 110^{\circ} 39^{\prime} \mathrm{E}\right)$.

\begin{tabular}{|c|c|c|c|c|c|c|c|c|c|}
\hline Date & Medium & $\begin{array}{c}\text { Depth } \\
\mathrm{cm}\end{array}$ & Salinity & $\begin{array}{c}\mathrm{Chl} a \\
\mu g . L^{-1}\end{array}$ & $\begin{array}{c}\text { POC } \\
\mu g . L^{-1}\end{array}$ & $\begin{array}{c}\mathrm{Hg}_{\mathrm{T}} \\
\text { pmol L }\end{array}$ & $\begin{array}{c}\mathrm{Hg}_{\mathrm{R}} \\
\text { pmol L } L^{-1}\end{array}$ & $\begin{array}{c}\mathrm{MeHg}_{\mathrm{T}} \\
\text { pmol L }\end{array}$ & $\begin{array}{c}\mathrm{MeHg}_{\mathrm{T}} / \mathrm{Hg}_{\mathrm{T}} \\
\% \\
\end{array}$ \\
\hline $11 / 11 / 09$ & Sea ice & $0-6$ & - & 0.07 & 252 & 22.33 & 17.9 & 0.145 & 0.6 \\
\hline $11 / 11 / 09$ & Sea ice & $30-36$ & 5.9 & 0.06 & 614 & 7.17 & 0.68 & 0.36 & 5 \\
\hline $11 / 11 / 09$ & Sea ice & $70-76$ & 4.9 & 0.52 & 226 & 3.54 & 0.78 & 0.321 & 9.1 \\
\hline $11 / 11 / 09$ & Sea ice & $108-114$ & 5.9 & 4.48 & 860 & 3.31 & 0.45 & 0.267 & 8.1 \\
\hline $11 / 11 / 09$ & Sea ice & $114-120$ & 11.2 & 91.3 & 11196 & 8.92 & 0.95 & - & - \\
\hline $14 / 11 / 09$ & Sea ice & $0-6$ & 1.7 & 0.1 & 288 & 28.42 & 10.39 & 0.082 & 0.3 \\
\hline $14 / 11 / 09$ & Sea ice & $30-36$ & 4.6 & 0.04 & 226 & 3.61 & 1.67 & $<0.045$ & $<1.3$ \\
\hline $14 / 11 / 09$ & Sea ice & $70-76$ & 4.4 & 0.36 & 205 & 0.9 & 0.27 & $<0.045$ & $<5.0$ \\
\hline $14 / 11 / 09$ & Sea ice & $106-112$ & 6.1 & 3.44 & 750 & 5.12 & 0.28 & $<0.045$ & $<0.9$ \\
\hline $14 / 11 / 09$ & Sea ice & $112-118$ & 12.1 & 247.62 & 25176 & 6.47 & 0.46 & 0.281 & 4.3 \\
\hline $14 / 11 / 09$ & Sack-hole brine & 50 & 54.5 & 0.05 & 749 & 12.69 & 11.15 & 0.083 & 0.7 \\
\hline $14 / 11 / 09$ & Sack-hole brine & 100 & 65.3 & 0.24 & 543 & 15.24 & 15.15 & 0.158 & 1 \\
\hline $14 / 11 / 09$ & Seawater & 0 & 33.7 & 0.68 & 95 & 44.4 & 25.89 & 0.155 & 0.3 \\
\hline $14 / 11 / 09$ & Seawater & 500 & 34.3 & 0.03 & 32 & 27.85 & 18.83 & 0.142 & 0.5 \\
\hline $14 / 11 / 09$ & Seawater & 1000 & 33.6 & 0.06 & 23 & 6.31 & - & 0.155 & 2.5 \\
\hline $17 / 11 / 09$ & Snow & - & - & - & - & 27.78 & 19.6 & 0.344 & 1.2 \\
\hline $17 / 11 / 09$ & Sea ice & $0-6$ & 5.5 & 0.32 & 289 & - & 10.63 & 0.129 & - \\
\hline $17 / 11 / 09$ & Sea ice & $30-36$ & 4.8 & 0.08 & 226 & 3.43 & 2.23 & 0.241 & 7 \\
\hline $17 / 11 / 09$ & Sea ice & $70-76$ & 4 & 0.22 & 205 & 6.51 & 2.41 & 0.247 & 3.8 \\
\hline $17 / 11 / 09$ & Sea ice & $106-112$ & 6.4 & 4.21 & 750 & 4.71 & 3.53 & 0.277 & 5.9 \\
\hline $17 / 11 / 09$ & Sea ice & $112-118$ & 11.2 & 81.2 & 25176 & 4.48 & 1.96 & 0.44 & 9.8 \\
\hline $17 / 11 / 09$ & Sack-hole brine & 50 & 57.1 & 0.22 & 748 & 14.67 & 6.84 & 0.115 & 0.8 \\
\hline $17 / 11 / 09$ & Sack-hole brine & 100 & 52.4 & 0.14 & 543 & 13.29 & 3.37 & 0.029 & 0.2 \\
\hline $17 / 11 / 09$ & Seawater & 0 & 33.9 & 0.04 & 95 & 17.24 & 9.94 & 0.284 & 1.6 \\
\hline $17 / 11 / 09$ & Seawater & 500 & 35.4 & 0.05 & 32 & 11.71 & 6.01 & 0.234 & 2 \\
\hline $17 / 11 / 09$ & Seawater & 1000 & 33.7 & 0.04 & 23 & 18.89 & 11.9 & 0.269 & 1.4 \\
\hline
\end{tabular}




\begin{tabular}{lccccccccc}
$20 / 11 / 09$ & Sea ice & $0-6$ & 1.9 & 0 & 153 & - & - & - & - \\
$20 / 11 / 09$ & Sea ice & $30-36$ & 5.2 & 0.21 & 476 & - & - & - & - \\
$20 / 11 / 09$ & Sea ice & $70-76$ & 3.6 & 0.08 & 315 & - & - & - \\
$20 / 11 / 09$ & Sea ice & $106-112$ & 6.6 & 2.17 & 951 & - & - & - \\
$20 / 11 / 09$ & Sea ice & $112-118$ & 12.3 & 126.8 & 15418 & - & - & - & - \\
$20 / 11 / 09$ & Sack-hole brine & 50 & 46.9 & 0.22 & 588 & 24 & 23.16 & $<0.045$ & $<0.2$ \\
$20 / 11 / 09$ & Sack-hole brine & 100 & 39.6 & 0.21 & 407 & 8.85 & 8.83 & 0.206 & 2.3 \\
$20 / 11 / 09$ & Seawater & 0 & 33.7 & 0.55 & 53 & 1.72 & 1.36 & 0.066 & 3.8 \\
$20 / 11 / 09$ & Seawater & 500 & 33.6 & 0.04 & 55 & 1.58 & 1.2 & 0.084 & 5.3 \\
$20 / 11 / 09$ & Seawater & 1000 & 33.3 & 0.01 & 36 & 1.21 & 1.15 & 0.078 & 6.5 \\
\hline
\end{tabular}


Electronic annex 3. Principal Component Analysis on salinity, particulate organic carbon (POC),

908 chlorophyll $a(\mathrm{Chl} a)$, total mercury $\left(\mathrm{Hg}_{\mathrm{T}}\right)$, reactive mercury $\left(\mathrm{Hg}_{\mathrm{R}}\right)$ and total methylated mercury $\left(\mathrm{MeHg}_{\mathrm{T}}\right)$

909 within the snow, ice, brine and seawater in the coastal sea ice environment $12 \mathrm{~km}$ northeast of the Casey

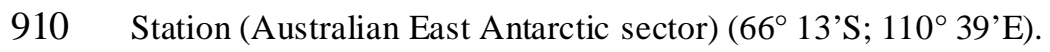

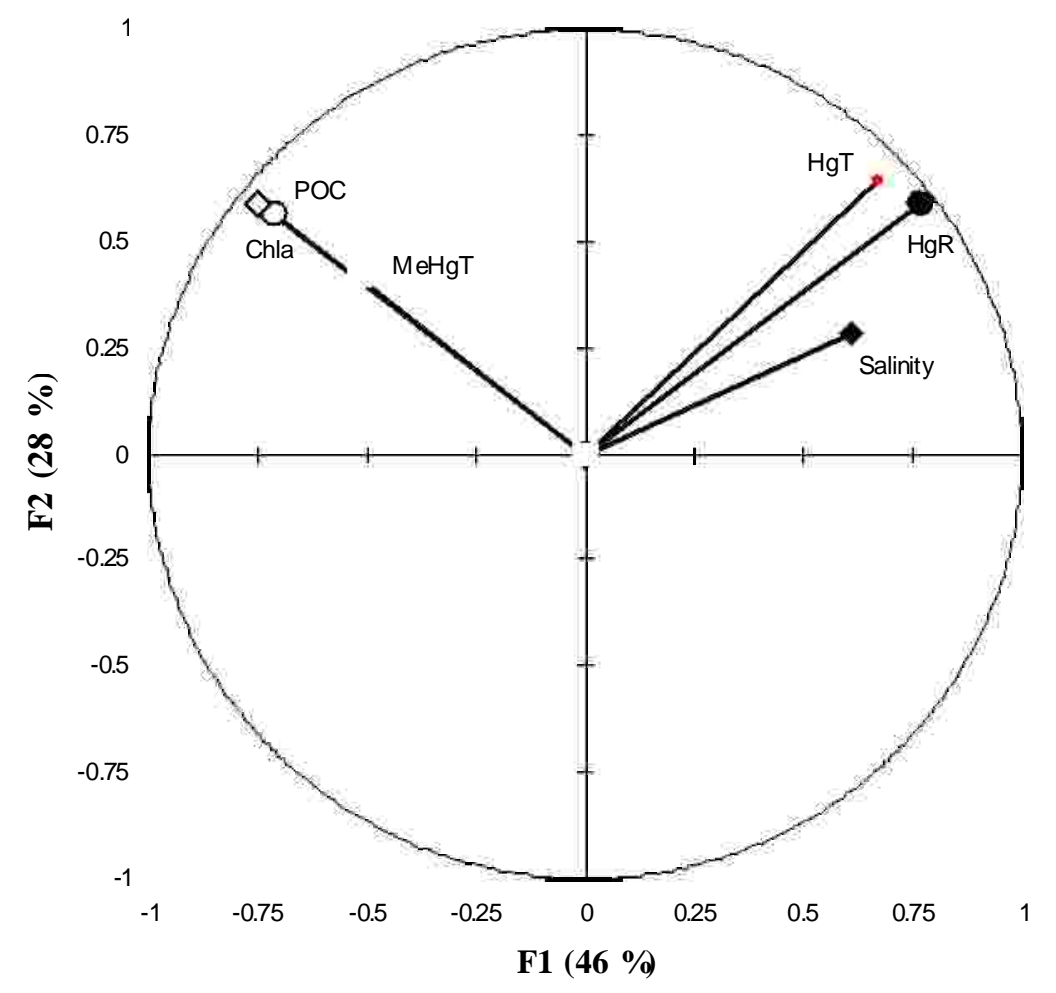

911 
918 Electronic annex 4. SR3 CASO-GEOTRACES transect. Vertical distribution of total methylated m ury $919\left(\mathrm{MeHg}_{\mathrm{T}}\right)$ against potential density evidencing latitudinal gradient along isopycnals.

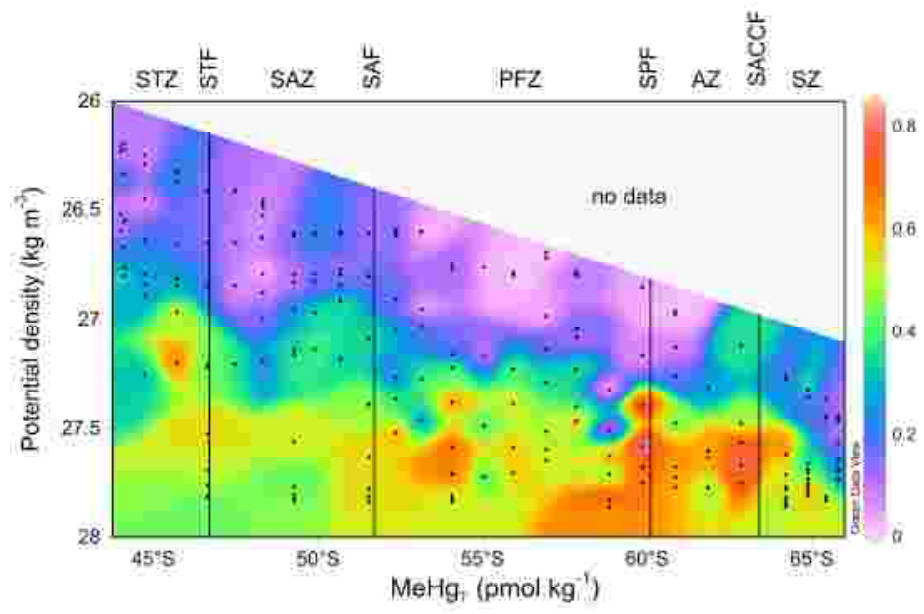

921 Electronic annex 5. SR3 CASO-GEOTRACES transect. Vertical distribution of apparent oxygen utilization

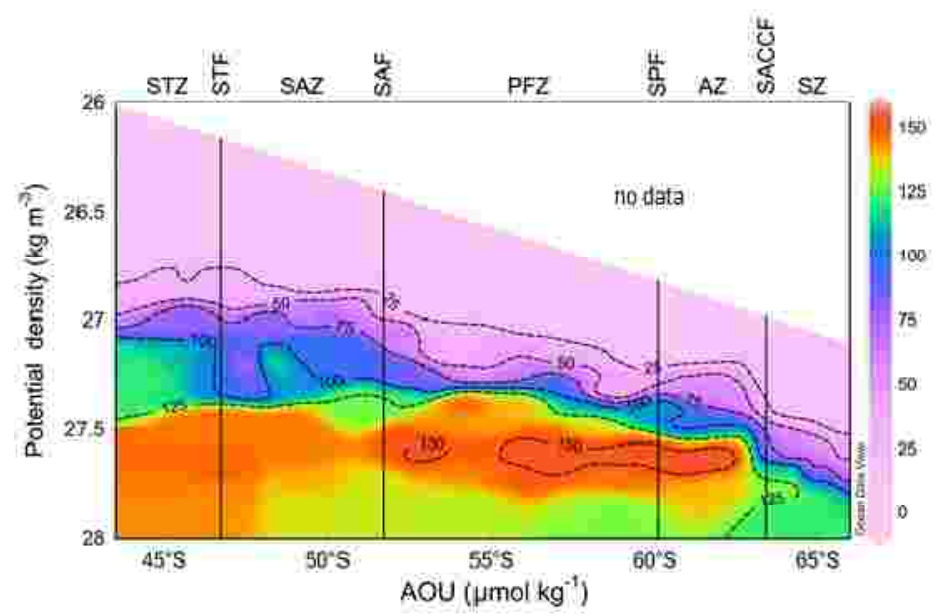


923 Electronic annex 6. Correlations between $\mathrm{MeHg}_{\mathrm{T}}$ concentrations and $\mathrm{AOU}$ within the first $1000 \mathrm{~m}$ of the 924 water column of the Southern Ocean (SR3 CASO-GEOTRACES section). STZ: Subtropical Zone; SAZ:

925 Subantarctic Zone; PFZ: Polar Frontal Zone; AZ: Antarctic Zone; SZ: Southern Zone.

\begin{tabular}{|c|c|c|c|c|}
\hline Zone & Station & $\begin{array}{l}\text { Regression coefficient } \\
\left(\mathrm{pmol}_{\mathrm{MeHg \textrm {T }}} / \mu \mathrm{mol}_{\mathrm{AOU}}\right)\end{array}$ & $\mathrm{R}^{2}$ & Significance $(\mathrm{p})$ \\
\hline SZ & 1 & 0.0031 & 0.939 & $<0.01$ \\
\hline SZ & 2 & 0.0040 & 0.876 & $<0.01$ \\
\hline $\mathrm{SZ}$ & 3 & 0.0050 & 0.976 & $<0.01$ \\
\hline $\mathrm{AZ}$ & 4 & 0.0028 & 0.467 & $>0.10$ \\
\hline $\mathrm{AZ}$ & 5 & 0.0028 & 0.751 & $<0.10$ \\
\hline $\mathrm{AZ}$ & 6 & 0.0033 & 0.894 & $<0.01$ \\
\hline $\mathrm{AZ}$ & 7 & 0.0042 & 0.979 & $<0.01$ \\
\hline $\mathrm{AZ}$ & 8 & 0.0051 & 0.941 & $<0.01$ \\
\hline PFZ & 9 & 0.0019 & 0.217 & $>0.10$ \\
\hline PFZ & 10 & 0.0034 & 0.885 & $<0.01$ \\
\hline PFZ & 11 & 0.0033 & 0.990 & $<0.01$ \\
\hline PFZ & 12 & 0.0037 & 0.953 & $<0.01$ \\
\hline PFZ & 13 & 0.0027 & 0.966 & $<0.01$ \\
\hline PFZ & 14 & 0.0039 & 0.930 & $<0.01$ \\
\hline PFZ & 15 & 0.0023 & 0.716 & $<0.10$ \\
\hline SAZ & 16 & 0.0023 & 0.802 & $<0.10$ \\
\hline SAZ & 17 & 0.0023 & 0.982 & $<0.01$ \\
\hline SAZ & 18 & 0.0023 & 0.544 & $>0.10$ \\
\hline SAZ & 19 & 0.0016 & 0.593 & $>0.10$ \\
\hline SAZ & 20 & 0.0016 & 0.791 & $<0.10$ \\
\hline SAZ & 21 & 0.0012 & 0.599 & $>0.10$ \\
\hline SAZ & 22 & 0.0028 & 0.611 & $<0.10$ \\
\hline STZ & 23 & 0.0024 & 0.941 & $<0.01$ \\
\hline STZ & 24 & 0.0039 & 0.915 & $<0.01$ \\
\hline STZ & 25 & 0.0020 & 0.597 & $<0.10$ \\
\hline STZ & 26 & 0.0050 & 0.430 & $>0.10$ \\
\hline STZ & 27 & 0.0002 & 0.163 & $>0.10$ \\
\hline
\end{tabular}

